Revista lus et Praxis, Año 23, № 2, 2017, pp. 213 - 250

ISSN 0717 - 2877

Universidad de Talca - Facultad de Ciencias Jurídicas y Sociales

Acusación constitucional y garantía política de la supremacía constitucional

Luis Alejandro Silva Irarrázaval

Trabajo recibido el 15 de enero de 2016 y aprobado el 17 de mayo de 2016

\title{
Acusación constitucional y garantía política de la supremacía constitucional ${ }^{*}$
}

\author{
Political guaranteE OF THE SUPREMACY
}

OF THE CONSTITUTION THROUGH IMPEACHMENT

\section{Luis Alejandro Silva Irarrázaval ${ }^{* *}$}

\section{Resumen}

Se plantea que la garantía de la supremacía constitucional también está entregada a órganos políticos. La tesis sostenida en este trabajo se desarrolla en el marco de la acusación constitucional: este sería un mecanismo de naturaleza eminentemente política que posiciona al Congreso como guardián último de la supremacía constitucional.

ABSTRACT

This paper develops on that the guarantee of supremacy of the Constitution lays also in hands of Congress, which should be considered as a final interpreter of the Constitution when judging impeachable offenses. The claim of this paper is unfolded on the light of impeachment given the political nature thereof. In the end, through impeachment, Congress is the final guardian of constitutional supremacy.

\section{PALABRAS CLAVE}

Acusación constitucional, Juicio político, Interpretación constitucional

KEY WORDS

Impeachment, Constitutional interpretation, Neo-constitutionalism

\section{Introducción}

Suele afirmarse que hay un solo intérprete final de la Constitución y que este es un tribunal ${ }^{1}$. En este trabajo se discute esta aseveración, proponiendo que el

\footnotetext{
* Este artículo se enmarca en el Proyecto Fondecyt Regular № 1140115, del cual soy Investigador Responsable. Agradezco a los profesores Mario Fernández, Sebastián Soto y Sergio Verdugo sus comentarios al borrador de este trabajo; a la Facultad de Derecho de la Universidad Austral de Chile por haberme dado la posibilidad de discutir las tesis aquí contenidas en su Seminario Austral; por último, agradezco a Raúl Herrera, mi ayudante en esta investigación.

** Profesor de Derecho Constitucional de la Facultad de Derecho de la Universidad de los Andes. Correo electrónico: Isilva@uandes.cl.

1 Una síntesis de esta posición y sus argumentos en relación con el Tribunal Constitucional, en SiLva (2012), pp. 575-582.
} 
Congreso también es un intérprete final de la Constitución. Específicamente, se postula que la interpretación de la causal del artículo $52 \mathrm{~N}^{0} 2$ de la Constitución, articulada por la Cámara de Diputados y el Senado a través de la acusación constitucional, es la última palabra acerca del sentido y alcance de dicho texto. En este sentido, puede decirse que el Congreso es un intérprete supremo de la Constitución.

La proposición contenida en este trabajo supone una concepción de la supremacía constitucional diversa de la dominante. La concepción dominante enfatiza la naturaleza jurídico-normativa de la Constitución y, consecuentemente, atribuye a los órganos jurisdiccionales la responsabilidad de su garantía última ${ }^{2}$. La supremacía constitucional se entiende, principal o exclusivamente, como el principio que refleja la posición jerárquicamente superior de la Constitución en el ordenamiento normativo, quedando como oscurecida su función estructurante de la organización del orden político. Aquí, en cambio, se resalta la naturaleza política de la Constitución y, por consiguiente, la necesidad de un guardián político de la supremacía constitucional ${ }^{3}$.

El análisis de la acusación constitucional revela que el Congreso actúa como intérprete final de la Constitución y, por ser esencialmente política la naturaleza del órgano que interpreta y del mecanismo por el que interpreta, se puede afirmar que la supremacía constitucional está garantizada también políticamente. Esta conclusión tiene una consecuencia interesante: nadie puede reclamar el monopolio de la garantía de la supremacía constitucional. Dicho de otro modo, significa que la supremacía constitucional está garantizada por varios guardianes.

En la primera parte de este trabajo se plantea la cuestión dentro de la cual el objeto de la investigación es relevante: se propone una concepción de la supremacía constitucional que enmienda la concepción dominante en una de sus características esenciales, que es su garantía jurisdiccional. Los tribunales no son los guardianes naturales de la Constitución sin más: caben otros tan idóneos como ellos. En la segunda parte se explica la naturaleza de la acusación constitucional en cuanto mecanismo político de garantía de la supremacía constitucional. La tercera y última parte se orienta a demostrar

\footnotetext{
2 Una caracterización de esta concepción que Ilamamos dominante, en Siıva (2009), pp. 23-36. El fenómeno conocido como neoconstitucionalismo extrema las proyecciones implícitas en esta concepción. Ver notas 14 y ss.

${ }^{3}$ La concepción de la Constitución es determinante en la definición de su guardián y sus mecanismos de garantía, como queda patente en el debate, todavía actual, entre Schmitt y KeLSEN (2009). Ver especialmente las pp. x-xii del Estudio Preliminar de Lombardi.
} 
que la interpretación de la Constitución hecha por el Congreso a través de la acusación constitucional es definitiva y que, por lo tanto, los tribunales no tienen el monopolio de la interpretación final de la Constitución.

No se nos escapa una objeción metodológica que pudiera hacerse contra este trabajo muy desde el principio del mismo y que es la falta de claridad que rodea las concepciones de lo jurídico y lo político que vertebran el argumento. Por una parte, se nos podría decir que el artículo descansa en la distinción entre lo político y lo jurídico, pero por otra, permanece indefinido qué se entiende por uno y otro. Aquí reconocemos la validez de este reparo, pero señalamos sus alcances también. Es cierto que no se explicita una definición de lo jurídico ni lo político, pero es una omisión deliberada, porque el esfuerzo resultaba inútil de antemano por dos razones. La primera, porque la complejidad de la materia supera los límites de esta investigación, por lo que necesariamente cualquier intento habría acabado en lugares comunes, empobreciendo el trabajo como consecuencia. La segunda, porque la tesis del artículo se sostiene al margen de esas definiciones explícitas. En efecto, tanto el objeto como la perspectiva de esta investigación ofrecen al lector un caso en el que la diferencia entre lo político y lo jurídico le resulta familiar. Sin necesidad de precisar dichos conceptos, es posible reconocer que existe una distinción entre ambos, y la forma como se trata esa distinción en el artículo se ajusta a la realidad en una medida al menos suficiente como para ofrecer una discusión con sentido. Es verdad que acompañada de esas definiciones podría haberse llegado a conclusiones más profundas y ricas en matices, pero es un precio que estuvimos dispuestos a pagar.

\section{Planteamiento de la cuestión}

El interés de una discusión como la que se aborda en este artículo depende de que se perciba la novedad-siempre relativa, por supuesto- de su tesis. Por ello es que en esta sección se caracterizará, en la primera parte, el marco teórico dominante en la escena nacional respecto del significado de la supremacía constitucional. En la segunda parte de esta sección se desarrollará a grandes trazos la tesis de este artículo.

\subsection{Concepción dominante de la supremacía constitucional}

La concepción dominante de la supremacía constitucional se caracteriza por dos notas: la relación entre supremacía y normatividad, y la naturaleza jurisdiccional de su garantía definitiva. 


\subsubsection{Supremacía y normatividad}

Actualmente, la idea de supremacía constitucional está íntimamente asociada al carácter normativo de la Constitución. La supremacía constitucional aparece indisociable de su fuerza normativa, porque si la Constitución no es aplicable por el juez, es inútil; y si no es suprema, no es Constitución. Este es el paradigma dominante en la materia hoy: la Constitución es suprema y normativa ${ }^{4}$. Esta definición se traduce en dos consecuencias que se asumen como necesarias y que son la directa aplicabilidad de la Constitución por parte del juez ${ }^{5}$ y que el garante último de la supremacía constitucional es un órgano jurisdiccional ${ }^{6}$. Vamos a centrar nuestra atención en la segunda de estas consecuencias.

En el plano teórico, podría decirse que la justicia constitucional en Chile -asumo que lo mismo podría decirse de otros muchos países- es tributaria de dos tradiciones: por una parte, la del judicial review norteamericano y, por otra, la de la teoría jurídica de Hans Kelsen ${ }^{7}$. Aunque ambas vertientes se diferencian entre sí sustancialmente en varios aspectos, las dos coinciden en asociar la supremacía de la Constitución a su naturaleza normativa ${ }^{8}$.

En Chile, esta asociación entre supremacía y normatividad de la Constitución se hizo presente con especial fuerza después del Golpe de $1973^{9}$. La fuerza normativa de la Constitución, asociada al carácter supremo de la norma constitucional, es una tendencia que ha ido expandiendo su radio de acción a través de la actividad jurisdiccional ${ }^{10}$. Esta dinámica puede

4 Una síntesis de esta caracterización, en García de Enterría (2006), p. 54.

${ }^{5}$ Fernández (2001); Cea (1999); Bulnes (1998).

${ }^{6}$ Carreño y Jaraquemada (2010); Núñez (2008); Fernández (2006).

7 Según García de Enterría (2006), p. 67. Este sería el caso de España.

${ }^{8}$ El judicial review norteamericano se origina en la sentencia Marbury v. Madison (1803), en que el juez Marshall razonó así: es deber del juez interpretar la ley; la Constitución es ley; luego, es deber del juez interpretar la Constitución. Casi 150 años después, en la sentencia Cooper v. Aaron (1958), la Corte Suprema explicitó algo que parecía estar implícito en el judicial review: si la Corte Suprema es el intérprete final de la Constitución, y la Constitución es la norma suprema, entonces la interpretación de la Corte es suprema. Kelsen, por su parte, postuló la supremacía normativa de la Constitución como una premisa de su teoría jurídica. Su doble condición de norma y suprema permite que funcione como criterio último de validez de las normas inferiores, KeLSEN (1995), p. 146.

${ }^{9}$ El recurso de protección, creado en 1976, vino en cierta medida a materializar la fuerza normativa de la Constitución, permitiéndoles a los jueces su aplicación directa. Cé (1996), p. 13.

${ }^{10}$ La evolución del recurso de protección es un antecedente que ilustra el punto. Hay consenso en que los tribunales han ampliado la interpretación de las garantías enumeradas en el artículo 20 de la Constitución, hasta alcanzar situaciones originalmente excluidas de su concepción. (GARCía y Verdugo (2013); Navarro (2012); Nogueira (2007); Pfeffer (2006). Esto ha ocurrido, principalmente, 
identificarse con el fenómeno de la constitucionalización del Derecho ${ }^{11} \mathrm{o}$ con el neoconstitucionalismo ${ }^{12}$.

La corriente llamada neoconstitucionalismo ilustra la predominancia que tiene la concepción de la Constitución como norma suprema. Esta corriente se caracteriza por el énfasis que pone en la directa aplicabilidad de la Constitución ${ }^{13}$. Aunque la doctrina en Chile haya quizá permanecido hasta ahora al margen de la parte más activa de esta tendencia ${ }^{14}$, pueden señalarse ejemplos que, en el fondo, obedecen a las mismas premisas ${ }^{15}$. Además, es posible constatar en la jurisprudencia casos que se inscriben en esta corriente ${ }^{16}$.

\subsubsection{Garantía jurisdiccional}

La garantía jurisdiccional de la supremacía constitucional obedece, en principio, a un doble motivo. Por una parte, a la exigencia lógica planteada por los atributos de la Constitución (normativa y suprema) ${ }^{17}$ y, por otra, a la necesidad -creada por la experiencia europea- de garantizar los derechos fundamentales con independencia del legislador ${ }^{18}$.

a través de la garantía del artículo 19 № 24, que ha dado pie al fenómeno de la propietarización de los derechos fundamentales, VERGARA (1991).

11 CEA (1996), p. 13: “... la constitucionalización del Derecho es el reconocimiento práctico de la supremacía de la Carta Fundamental". CEA (2006), p. 14, se refiere al efecto expansivo de la justicia constitucional en desmedro del espacio del legislador, y explica: "Es el efecto de la supremacía constitucional, extensivo a la imperatividad directa del Código Político y que así debe ser entendido por la Justicia Constitucional". Una mirada crítica sobre las premisas de este fenómeno y sus consecuencias, en Corral (2014); Correa (2009); Guzmán Brito (2001), pp. 71-77; Domínguez (1996).

12 Pozzolo (2009), pp. 88-91. El neoconstitucionalismo descansa en la constitucionalización de un catálogo detallado de derechos fundamentales y en la justiciabilidad de la Constitución (que es la norma suprema) por un órgano predispuesto para tal efecto: el juez de las leyes. Carbonell (2010), pp. 159-162, identifica entre los elementos del neoconstitucionalismo los siguientes tres: garantía jurisdiccional de la Constitución, fuerza vinculante de la Constitución y aplicación directa de las normas constitucionales. CRISTI y RUIZ-TAGLE (2014), p. 155, sintetizan el neoconstitucionalismo de Carbonell como "un nuevo modelo de Estado que se propone hacer efectivos los principios constitucionales de supremacía y aplicación directa de la carta fundamental en todo el ordenamiento jurídico".

13 Carbonell (2009), pp. 9 y 10.

14 Tendencia que, desde cierta perspectiva, puede calificarse como una ideología. Aldunate (2010), p. 100; NúÑEZ (2010).

15 NúÑEZ (2012); NúÑEZ (2013).

${ }^{16}$ Es lo que busca mostrar NúÑEZ (2010) respecto de la jurisprudencia del Tribunal Constitucional.

17 Ver nota 10.

18 García de Enterría (2004), pp. 78 y ss.; Barzotto (2013), p. 2. Este segundo motivo es posterior en el tiempo y ha sido el factor de la expansión del ámbito de la justicia constitucional. Aunque actúa 
En la medida en que la Constitución se entiende como norma jurídica, se sigue naturalmente la competencia de los tribunales para aplicarla. A esta circunstancia se le añade el carácter supremo de la Constitución, que convierte a los tribunales en los intérpretes de la norma suprema. En función de la organización y dinámica de los sistemas jurisdiccionales, existen tribunales que clausuran el proceso judicial declarando el sentido final de las normas jurídicas en juego. Tratándose de la Constitución, entonces, la interpretación definitiva o última de su texto correspondería a los órganos jurisdiccionales que cierran un proceso ${ }^{19}$.

Esto no supone desconocer que todos los órganos del Estado están obligados a respetar y hacer respetar la Constitución, sino destacar que, en última instancia, corresponderá a los tribunales zanjar las controversias que suscite la interpretación de la Constitución.

\subsection{Otra concepción sobre la supremacía constitucional}

Frente a la concepción dominante de la Constitución, en que normatividad y supremacía se traducen, finalmente, en su garantía jurisdiccional con carácter definitivo, aquí se plantea una concepción que relativiza el valor explicativo de esas dos características de la Constitución y, en consecuencia, la posición de los tribunales como intérpretes de la Constitución.

Una adecuada comprensión de la Constitución debe huir de los extremos que naturalmente reclaman para sí los dos elementos que componen su naturaleza, jurídica y política ${ }^{20}$. Frente a la concepción dominante, que enfatiza el carácter jurídico-normativo de la Constitución, hasta el punto en que su naturaleza pareciera agotarse en esta nota, se proponen aquí razones para reafirmar su componente político ${ }^{21}$. Este esfuerzo significa sostener la existencia de una garantía política de la supremacía constitucional, junto a la garantía jurisdiccional. Ahora bien, esta garantía política no debe entenderse con carácter subsidiario a la jurisdiccional, como asumiendo que la última palabra siguiera perteneciendo a los tribunales. En realidad, esto debe ser entendido en el sentido de que la Constitución tiene un defensor que interpreta

sirviéndose del primero, ni Kelsen ni Marshall habrían podido imaginar la extensión que alcanzarían sus premisas.

19 Típicamente se señala al Tribunal Constitucional, pero se admite que sería una función parcialmente compartida con la Corte Suprema. Ver nota 25.

${ }^{20}$ Nieto (1983), p. 374: "La Constitución es, al tiempo, un fenómeno jurídico y político, que no puede ser comprendido unilateralmente sin grave riesgo de disfunción".

${ }^{21}$ FeRNÁNDEZ (2013), pp. 288-293, se refiere al problema de la equívoca naturaleza de la Constitución, si jurídica o política. 
definitivamente su texto (letra y espíritu) según criterios que se corresponden con su componente político más que con su componente jurídico-normativo.

Es un tópico afirmar que todos los órganos del Estado deben velar porque se respete la Constitución. Sin embargo, se asume que debe existir un órgano que zanje aquellas controversias que tengan su origen en diferentes interpretaciones sobre el significado de la Constitución. A este órgano se le suele considerar como el guardián de la supremacía constitucional en sentido propio. El atributo que caracteriza a este órgano es que su interpretación de la Constitución es definitiva; se dice que tiene la última palabra o que es el intérprete supremo ${ }^{22 .}$

En ninguna parte de su texto, la Constitución especifica quién sea el guardián de su primacía jerárquica. Es más, ni siquiera señala expresamente que haya un guardián de la supremacía constitucional. En general, la doctrina se inclina por señalar al Tribunal Constitucional como el supremo intérprete de la Constitución ${ }^{23}$, pero el peso que se le asigne a esta tendencia estará condicionado por el peso que se le dé a la premisa en que descansa y que es el carácter normativo de la Constitución. Al proponer un órgano político como garante final de la supremacía constitucional, no se pretende desconocer la naturaleza jurídica de la Constitución ni la competencia de los tribunales para custodiar su supremacía, sino ampliar la mirada para abarcar también la naturaleza política de la Constitución ${ }^{24}$.

El reconocimiento de la naturaleza compuesta de la Constitución-jurídica y política- y los guardianes correspondientes es la tesis general de este artículo. Esto implica como consecuencia que ningún órgano puede pretender el monopolio de la interpretación definitiva de su texto. La tesis particular consiste en afirmar que la acusación constitucional es un mecanismo de protección de la supremacía constitucional en el que se cumple la tesis general. Es decir, que la acusación constitucional supone un guardián político que interpreta definitivamente la Constitución ${ }^{25}$.

\footnotetext{
22 Nogueira (2010), p. 101: "La superioridad de la Constitución lleva a la superioridad del intérprete de la Constitución (...), el que se constituye en el órgano de cierre del ordenamiento jurídico".

${ }^{23}$ Nogueira (2010); Zapata (2008); Nogueira (2005); Colombo (2005). También se ha dicho que es una función compartida por la Corte Suprema, BORDALí (2007), pp. 530, 531, 535 y 536. ATRIA (2000), por su parte, ha sugerido alguna vez que el intérprete supremo fuera político.

${ }^{24}$ Verdugo (2013) defiende una tesis parecida, en el contexto de la objeción democrática contra el control de constitucionalidad: en la medida en que se acepte que los jueces no monopolizan la interpretación definitiva de la Constitución, los efectos de sus decisiones son menores. En el fondo, invita a no confundir la supremacía constitucional con la supremacía judicial.

25 No se nos esconde la aparente contradicción que puede surgir entre la afirmación de que nadie tiene el monopolio de la interpretación definitiva y que hay varios intérpretes últimos de la Constitución.
} 


\section{La acusación constitucional: un mecanismo eminentemente político}

La acusación constitucional es un mecanismo de resguardo de la supremacía constitucional porque, a través suyo, el Congreso vela por el cumplimiento de ciertos estándares constitucionales por parte de algunos importantes actores de la organización estatal ${ }^{26}$. Sostener que el Congreso actúa como guardián de la supremacía constitucional significa, en este trabajo, afirmar dos $\operatorname{cosas}^{27}$. En primer lugar, que la acusación constitucional es un mecanismo de naturaleza eminentemente política. Esto es lo que desarrollaremos en la presente sección. En segundo lugar, que a través de la acusación constitucional, el Congreso actúa como un intérprete definitivo de la Constitución, que es lo que se aborda en la siguiente sección.

Para efectos de este trabajo es importante recalcar la naturaleza eminentemente política de la acusación constitucional, porque sobre ella descansa la tesis que sostenemos. Puesto que se trata de demostrar que la Constitución no es ni principal ni exclusivamente una realidad jurídico-normativa, es necesario demostrar que la acusación constitucional es un mecanismo de garantía que actualiza la dimensión política de la supremacía de la Constitución.

Desde tres perspectivas complementarias queremos justificar el carácter eminentemente político de la acusación constitucional. La primera es histórica y se orienta a demostrar cómo la institución en Chile ha ido perfilándose en el tiempo cada vez más como un instrumento de responsabilidad política que jurídica. La segunda es dogmática y tiene el propósito de poner de manifiesto el carácter más político que jurídico de la acusación constitucional a través del análisis de su estatuto normativo. La tercera perspectiva es empírica. Aquí se trata de resaltar el carácter político de la acusación constitucional, deduciéndolo del uso que en la práctica ha hecho de ella la Cámara de Diputados durante la vigencia de la Constitución.

\subsection{Perspectiva histórica}

La acusación constitucional no es una creación original del Derecho Constitucional chileno. Sus antecedentes se reparten entre el Derecho indiano

¿Es lógico hablar de más de una interpretación final? La respuesta a esta cuestión dependerá de cómo se conciba la naturaleza de la Constitución. Si se la concibe como un compuesto jurídico-político, podría entonces defenderse la idea de que la fijación de su significado admite la participación de órganos distintos, jurídicos y políticos.

26 Bronfman (2005), p. 90.

27 Otros que han reconocido al Congreso como guardián de la supremacía constitucional, en un rol paralelo al que ejerce, por ejemplo, el Tribunal Constitucional, Garrote (2012), p. 408; Cea (2007), p. 4. 
y la institución del juicio de residencia, el Derecho inglés y el impeachment parlamentario, y el Derecho de los Estados Unidos y su peculiar recepción del impeachment inglés ${ }^{28}$. El grado de influencia que estas fuentes tuvieron en la configuración del mecanismo nacional es variado. La del Derecho indiano se notó más en los primeros ensayos constitucionales, pero finalmente desapareció, absorbiéndose en la experiencia inglesa ${ }^{29}$. El impeachment inglés, en cambio, modulado por la Constitución francesa de 1815, habría sido el modelo adoptado por el constitucionalismo criollo en su proyecto más duradero, la Constitución de $1833^{30}$. La experiencia de los Estados Unidos no habría sido considerada en esta primera etapa y, en cambio, habría servido como referencia en la reforma constitucional de $1874^{31}$.

Hay buenas razones para defender que, originalmente, la acusación constitucional quedó en la Constitución de 1833 como mecanismo para hacer eficaz la responsabilidad penal de los altos funcionarios acusables ${ }^{32}$. El artículo 98 de su texto es elocuente en este sentido: "El Senado juzgará al Ministro acusado ejerciendo un poder discrecional, ya sea para caracterizar el delito, y para dictar la pena" ${ }^{\prime 33}$. La naturaleza jurídica de este mecanismo diseñado para perseguir la responsabilidad criminal no se vería afectada por el hecho

${ }^{28}$ Es frecuente la referencia al modelo norteamericano cuando se explica la institución chilena, Nogueira (2013), pp. 225-228; Ulloa (2009), pp. 16 y ss.; Martínez y Rivero (2004), pp. 35 y ss.), pero son referencias indocumentadas o inconducentes. Aparte de algunas coincidencias que dan gran plausibilidad a la tesis de la influencia norteamericana (ver nota 43), quizá el motivo que explica tanta referencia con tan poca evidencia que la apoye sea el hecho de que los Estados Unidos fue el primer régimen presidencial en adoptar una institución típica de un régimen parlamentario.

${ }^{29}$ Martínez (1965) pesquisa la pervivencia del juicio de residencia hasta la Constitución de 1925. Aunque admite que muy tempranamente -hacia 1812- se le confunde con el juicio político, concluye que en el texto constitucional de 1925 "se encuentra aún vigente la vieja institución (...) en todo su vigor conceptual" (p. 207). La verdad es que para sostener esta afirmación, no vemos entre sus fundamentos más que algunas características accidentales típicas de la residencia que caracterizan todavía a la acusación constitucional, como el tiempo para acusar al Presidente y sus ministros después de terminado su período y en la condición de que durante este tiempo no pueden ausentarse del territorio de la República.

30 BRAHM (2007), pp. 108-109.

31 Ver notas 43, 64 y 104.

32 SChweitzer (1972), p. 69. "El texto de 1833 constituía propiamente un juzgamiento penal entregado -en definitiva- al arbitrio del Senado".

33 Subrayado es nuestro. Mariano Egaña, quien tuvo una notable incidencia en la redacción de la Constitución, propuso en su voto particular que los ministros de despacho podían ser acusados por la Cámara de Diputados solo para perseguir la responsabilidad penal: en un modelo presidencial como el que defendía, los ministros responden por sus actuaciones políticas única y exclusivamente al titular del Ejecutivo. BraHm (2007), pp. 130-131. 
de que fuera el Congreso quien acuse y decida, porque en el cumplimiento de esta función actúa como un órgano jurisdiccional en sentido propio ${ }^{34}$.

La particular configuración de los gobiernos durante los tres primeros decenios de vigencia de la Constitución de 1833 (1831-1861) explicaría que no haya habido más que tres acusaciones hasta $1925^{35}$. En 1868 se acusó al Presidente de la Corte Suprema, Manuel Montt, y a otros ministros de la Corte. La finalidad política con que se hizo uso de la acusación constitucional en este caso no escapó a nadie en su época ${ }^{36}$. No es coincidencia que cinco años después se haya reformado la Constitución en este punto ${ }^{37}$. En efecto, la reforma de 1874 puede interpretarse como un reconocimiento de la nueva dinámica que comienza a dominar las relaciones entre el Congreso y el Ejecutivo y, en consecuencia, si bien se admite la existencia de un mecanismo de presión como la acusación constitucional, su alcance se reduce y se enfoca más en lo político ${ }^{38}$.

${ }^{34}$ Quizá sea esta la característica del sistema inglés que más hondamente caló en la concepción local de la acusación constitucional, porque el funcionamiento del Parlamento como corte de justicia de altos dignatarios era entonces una práctica originalmente inglesa. En este sentido, creemos se equivocan quienes afirman la naturaleza política del juicio promovido por el impeachment. NogUeIRA (2013), p. 225; UlLOA (2009), p. 21 nota 24, y pp. 27 y 28. De hecho, BLACKSTONE (1795), IV, pp. 258 y ss., enseña que el impeachment es el procedimiento seguido ante el Parlamento, que actúa como la más alta corte de jurisdicción criminal. Este antecedente no pudo haber sido desconocido para Egaña, atendida la difusión de la obra de Blackstone en Inglaterra y su estadía allí como Ministro Plenipotenciario en 1824. LASTARRIA (1865), pp. 105-106, entendió que la facultad del Senado para juzgar delitos obedeció al temor de que los tribunales ordinarios faltaren a su deber en atención a la investidura de los funcionarios. Galdames (1926), p. 930, dice del Senado que, para conocer las acusaciones formuladas por la Cámara de Diputados, "tenía la obligación de constituirse (...) en alta corte de justicia".

35 Loveman y LiRa (2000), p. 10. Curiosamente, solo en Huneeus (1891a), p. 189, y en Vial (1934), p. 81 y ss., hemos encontrado referencia a la primera acusación, que tuvo lugar en 1850 contra el intendente de Aconcagua.

36 Loveman y LiRA (2000), pp. 11-14.

${ }^{37}$ El texto del artículo 98 reformado quedó así: "El Senado juzgará al ministro procediendo como jurado y se limitará a declarar si es culpable del delito o abuso de poder que se le imputa". SCHWEITZER (1972), pp. 69 y 72: “... la reforma de 1874 (...) dio a la institución sus verdaderas características de juicio político (...). Esta restricción conceptual ['se limitará a declarar'], indispensable para los reformadores de 1874, es un primer aspecto de la reacción que el sistema introducido constituía respecto del que ese año se hizo desaparecer".

38 Según Huneeus (1933), pp. 74-76, el paquete de reformas constitucionales que incluyó "la más fácil responsabilización de los Ministros de Estado" refleja las tendencias de un gobierno parlamentario que, a través del texto de la Constitución, habría promovido un equilibro más perfecto entre el Congreso y el Ejecutivo. En favor de esta tesis podría también señalarse el hecho de que en 1875 el legislador haya fortalecido la autonomía del Poder Judicial y deslindado la responsabilidad ministerial de los jueces, en un intento por acotar los márgenes de la responsabilidad que puede perseguirse a través de la acusación constitucional. Martínez y Rivero (2004), pp. 53-54; Campos (1963), p. 190; Heise 
Lo que originalmente habría respondido a la necesidad de garantizar que nadie en la república quedara eximido de responsabilidad jurídica aprovechándose de su investidura, se convirtió en un mecanismo de compensación entre los poderes políticos ${ }^{39}$. Este cambio en la concepción de la acusación constitucional va acompañado del rechazo a la idea de un poder jurisdiccional radicado en el Congreso ${ }^{40}$. El Congreso, cuando promueve y falla una acusación constitucional, no está actuando como una corte de justicia, sino como un poder político. Y la acusación constitucional deja de ser un expediente para juzgar criminalmente a las altas investiduras y se transforma en uno de los resortes que mantiene balanceada la estructura de los poderes del Estado ${ }^{41}$.

La Constitución de 1925 corrigió los excesos del parlamentarismo, fortaleciendo la autoridad del Presidente de la República. Pero la lógica política de la acusación constitucional ya estaba instalada. De ello da cuenta el hecho de que el entonces Presidente, Arturo Alessandri, habría exigido que el procedimiento para acusar al titular del Ejecutivo fuera ágil y expedito, como una forma de compensar la ampliación de los poderes presidenciales ${ }^{42}$. En esta lógica se inscriben también los cambios introducidos en el texto de la

(1954), pp. 91-92. Povez del Villar (1963), p. 46: "Al simplificarse el procedimiento [de la acusación constitucional], se cumplió el propósito de restringir las facultades del Ejecutivo aumentando las del Congreso". Un signo del enfoque hacia lo político que experimentó la acusación constitucional con la reforma de 1874 es la sanción establecida para el caso de que se acogiera la acusación contra un ministro: destitución del cargo. Esta es una consecuencia de orden político. SchweITZER (1972), p. 70.

39 Lastarria (1865), p. 81, defiende la facultad de las Cámaras para acusar y responsabilizar a los ministros, porque tiene un poder conservador de equilibrio político y "ofrece una importante garantía contra los desmanes del poder ejecutivo".

40 LASTARRIA (1865), pp. 83 y 85.

${ }^{41}$ Este es el punto donde la experiencia de los Estados Unidos de Norteamérica podría haber influido, y esa es la opinión de RolDÁn (1913), p. 346. No obstante carecer de prueba documental que nos permita afirmarlo, nos sentimos forzados a hacer algunos comentarios en favor de esa tesis. En primer lugar, fue una innovación de la Constitución Federal de 1787 la de restringir las penas del culpable a la destitución del cargo y la inhabilidad para ocupar cargos en el futuro (artículo 1 sección III cláusula $7^{\mathrm{a}}$ ). No sería raro, aunque no nos consta, que la reforma de 1874 haya tomado la primera parte de ella. Es, por lo demás, la opinión de Bronfman et al. (2013), pp. 342 y 343. En segundo lugar, el quórum de dos tercios de los senadores presentes para declarar la culpabilidad del Presidente es idéntico al quórum exigido por la Constitución Federal (artículo 1 sección III cláusula $6^{\mathrm{a}}$ ).

42 Actas (1925), pp. 72-80, 192 ss. y 489 y ss.; Bronfman et al. (2013), p. 331; Ulloa (2009), p. 45. El hecho de que el quórum para acoger la acusación contra el Presidente se haya elevado a los dos tercios de los senadores en ejercicio confirma la inspiración política de la institución: es la lógica del equilibrio de los poderes. 
nueva Constitución, que debilitan la identificación de la acusación constitucional con un proceso judicial ${ }^{43}$.

Por último, la Constitución de 1980 introdujo varias modificaciones a la acusación constitucional que, pese a las vacilaciones experimentadas en la Comisión de Estudio de la Nueva Constitución (CENC) acerca de su naturale$\mathrm{za}^{44}$, reflejarían su vocación política y no judicial. Entre las más significativas habría que mencionar el agravamiento de la sanción del funcionario destituido por medio de la restricción de un derecho típicamente político: la prohibición de desempeñar funciones públicas, sean o no de elección popular ${ }^{45}$. Elocuente también resulta el condicionamiento de los efectos de la declaración de culpabilidad para efectos de la responsabilidad civil o criminal ${ }^{46}$, porque con esta cláusula estaría distinguiendo claramente la responsabilidad que se persigue a través de la acusación constitucional de la que se persigue a través de los tribunales de justicia ${ }^{47}$.

La acusación constitucional en el constitucionalismo chileno se explica mejor si se la entiende como un procedimiento que, originalmente concebido para garantizar jurisdicción criminal para los más altos dignatarios de la república, evolucionó hacia un mecanismo del engranaje de pesos y contrapesos que conserva el equilibrio de los poderes estatales. Los sucesivos cambios de los textos constitucionales sobre la institución darían cuenta de esta transformación: lo que nació como un procedimiento judicial terminó siendo un resguardo político del Congreso frente a los poderes Ejecutivo y Judicial ${ }^{48}$.

\subsection{Perspectiva dogmática}

Desde esta perspectiva corresponde analizar el estatuto normativo vigente de la acusación constitucional, con el objetivo de desentrañar la naturaleza eminentemente política del mecanismo. Los elementos de su composición que

\footnotetext{
${ }^{43}$ Reemplazo del verbo "juzgar" del artículo $42 \mathrm{~N}^{\circ} 1$ por el de "conocer", y reemplazo del verbo "juzgará" del artículo $42 \mathrm{~N}^{\circ} 2$ por el de "resolverá".

${ }^{44}$ Ver notas 79 y ss.

45 Ver notas 68 y ss.

${ }^{46}$ El artículo $49 \mathrm{~N}^{\circ} 1$ inciso $4^{\circ}$ (actual artículo $53 \mathrm{~N}^{\circ} 1$ inciso $4^{\circ}$ ) dispuso: "El funcionario declarado culpable será juzgado de acuerdo a las leyes por el tribunal competente, tanto para la aplicación de la pena señalada al delito, si lo hubiere, cuanto para hacer efectiva la responsabilidad civil por los daños y perjuicios causados al Estado o a particulares". Cursivas nuestras. Ver notas 84 y ss. sobre el efecto de cosa juzgada de las decisiones del Senado.

47 ZúÑIGA (1993), p. 715.

${ }^{48}$ Obviamente, el estadio actual de su evolución es transitorio: todavía hay vestigios de su origen que se mezclan y confunden con las nuevas formas que ha ido adquiriendo.
} 
se estudiarán son: los sujetos, activos y pasivos; las causales de acusación; la decisión como jurado y las sanciones aplicables.

Los sujetos pasivos de la acusación constitucional. El listado de sujetos que pueden ser acusados constitucionalmente refleja una intención clara del constituyente: comprende a las más altas autoridades del Estado ${ }^{49}$. Para descubrir el sentido de esta selección, ella debe entenderse alineada con la finalidad de la acusación constitucional. ¿Cuál podría ser el fin que justifique la selección de un conjunto de autoridades como las enumeradas en el artículo $52 \mathrm{~N}^{\circ} 2$ de la Constitución? La respuesta deberá tener que ver con aquello que tienen en común estas autoridades y que podría expresarse en términos de responsabilidad en la conducción de los negocios del Estado ${ }^{50}$. Con esta caracterización de los sujetos pasivos aflora una nota clave de la acusación constitucional: la dimensión política. No cualquier sujeto puede ser acusado constitucionalmente, sino solo aquellos que tienen una especial responsabilidad de velar por la cosa pública. Un elemento que viene a sumarse a esta respuesta, profundizando el significado político de la acusación constitucional, es el hecho de que los parlamentarios no sean sujetos pasivos de ella ${ }^{51}$.

\footnotetext{
49 Bronfman et al. (2013), p. 325. Por supuesto que la enumeración admite críticas: ¿por qué se incluye al Contralor General de la República y se excluye, en cambio, a los ministros del Tribunal Constitucional?, ¿por qué se incluye al Comandante General del Ejército y se excluye al Director General de Carabineros? Sin embargo, estas críticas no alteran la lectura de la lógica que justifica, en general, al conjunto de sujetos acusables.
}

${ }^{50}$ Bronfman et al. (2013), pp. 326-327: "[la acusación constitucional estaría reservada para juzgar a las magistraturas] que por su autoridad representan un punto crítico en el mapa de los intereses nacionales"; SIIVA (2000), p. 181: "[La] substancia del proceso [de acusación constitucional gira en torno] a la responsabilidad asumida en la dirección general de la colectividad, raíz del juicio político". Ver nota 59. Durante el reinado de Carlos II (1660-1685), e inspirado en el derecho germánico, el impeachment se amplió a aquellas conductas que afectaran al pueblo (o bien público). Puesto que la House of Commons representa al pueblo, o está más cerca de él, era natural que tuviera el poder para acusarlos en calidad de ofendido, BLACKSTONE (1795), pp. 260-261.

51 Alessandri entendió que la posibilidad de acusar constitucionalmente al Presidente de la República durante su mandato era la justa compensación por la amenaza que para los mismos ciudadanos suponía la ampliación de los poderes presidenciales. Y el poder para acusar radica en la Cámara de Diputados, porque representa a los ciudadanos. Actas (1925), p. 74. Por esta razón, los diputados no serían sujetos activos del juicio político: porque actúan como corporación en representación de la soberanía nacional. SiLva (2000), p. 130. La CENC, por su parte, reconoció que los peligros de politización inherentes a la acusación constitucional quedan prácticamente anulados al radicarse esta atribución en el Congreso, el más político de los órganos estatales. Hay un factor histórico indiscutible que explica la radicación de esta atribución en el Congreso: el impeachment era originalmente un procedimiento judicial que se tramitaba en el Parlamento, constituido como la más alta corte de justicia. En los Estados Unidos fueron los propios parlamentarios quienes decidieron 
Los sujetos activos de la acusación constitucional. El hecho de que sea el Congreso, y solo el Congreso, quien tiene la facultad para perseguir la responsabilidad nacida de actuaciones que dañan la confianza pública en las autoridades políticas, habla en forma elocuente acerca de la naturaleza política de la acusación constitucional, porque el Congreso es el órgano político por antonomasia. Lo dicho vale con independencia de la discusión acerca de si el Congreso ejerce funciones jurisdiccionales o no cuando decide una acusación constitucional, pues seguiría siendo un órgano político aunque las ejerciera ${ }^{52}$. Las razones históricas de que esta atribución corresponda al Congreso han sido sustituidas por aquellas que explican la función política de la acusación constitucional. Si el Congreso puede acusar constitucionalmente no es porque ofrezca las garantías de un tribunal de justicia, sino porque debe tener instrumentos para conservarse en equilibrio político con los demás poderes estatales, especialmente con el Ejecutivo. La circunstancia de ser la acusación constitucional una atribución exclusiva del Congreso confirma esta interpretación ${ }^{53}$. En la misma dirección debe entenderse el hecho de que senadores y diputados estén excluidos del conjunto de autoridades susceptibles de ser acusadas constitucionalmente ${ }^{54}$.

Las causales de la acusación constitucional. El conjunto de las causales de la acusación constitucional permite inferir también una clara intencionalidad del constituyente. Pese a la variedad de conductas cubiertas por las diferentes causales, es obvio que todas responden a la misma lógica: la protección de la confianza pública depositada en algunas de las autoridades estatales más importantes. En este sentido, vale para Chile lo que Hamilton dijera de las causales de la Constitución Federal de 1787: "Se trata de las ofensas que nacen de la mala conducta de los hombres públicos o, en otras palabras, del abuso o violación de la confianza pública. La naturaleza de estas ofensas permite que se les califique con peculiar propiedad como políticas, en cuanto causan

que los senadores no estaban sujetos al impeachment, lo que puede explicarse por varios motivos. StORY (1858), II, § 791-793; GeRDHART (1996), pp. 75-77.

${ }^{52}$ La tendencia a caracterizar la naturaleza de la acusación constitucional como un compuesto jurídico-político demuestra, en último término, la imposibilidad de concebirla como exclusivamente jurídica o jurisdiccional. Esta dificultad comprende (como causa y/o como efecto) la imposibilidad de encasillar al Congreso como un órgano jurisdiccional exclusivamente, aunque se lo pueda Ilamar tribunal en sentido amplio, esto es, como órgano colegiado que decide sobre una acusación.

53 ZúNIIGA (1993), p. 722.

${ }^{54}$ Ver nota 53. 
daños a la sociedad misma directamente" ${ }^{\prime \prime 5}$. El motivo para individualizar estas conductas y juzgarlas a través de un procedimiento como la acusación constitucional es su connotación política ${ }^{56}$. Su ilicitud depende esencialmente del cargo y función que cumple el sujeto ${ }^{57}$. La gravedad de estas conductas no está en la cuantía del daño, sino en su impacto en la confianza sobre las autoridades públicas y, como consecuencia, en la sociedad toda ${ }^{58}$. De hecho, la Constitución no especifica medidas en la descripción de los ilícitos: sin importar los montos comprometidos, la participación de un ministro en actos de soborno, por ejemplo, es siempre susceptible de ser perseguida a través de la acusación constitucional. La amplitud de las causales es otro elemento que reafirma la orientación política de la acusación constitucional ${ }^{59}$.

La decisión como jurado ${ }^{60}$. El tener el Senado que decidir la acusación constitucional como jurado podría ser visto por alguno como una nota del carácter prevalentemente jurisdiccional de la acusación constitucional. Sin embargo, esta característica de la institución responde más bien a su finalidad política. En efecto, fue la reforma constitucional de 1874, que rediseñó la

\footnotetext{
55 Hamilton (1788). La traducción es nuestra.

${ }^{56}$ Bronfman et al. (2013), p. 326: el enjuiciamiento de estas conductas abarca "campos pertenecientes al orden político, sea en relación con el ordenamiento constitucional, sea respecto de la conducción superior del Estado". En la acusación constitucional contra el general Pinochet (1998) se aduce este motivo para explicar por qué se interpone ante el Congreso y no ante un órgano jurisdiccional: "... el Poder Judicial no es apto para conocer de procesos cuya apreciación se ajusta a reglas distintas de las que rigen a los delitos comunes. El conocimiento y fallo de una acusación constitucional abarca no sólo aspectos jurídicos sino también otros pertenecientes al orden político". Sesión 1ª (1998), p. 27.

57 Martínez y Rivero (2004), p. 74: “... las causales de acusación están establecidas en estricta relación con la función ejercida por el funcionario (...) y por actuaciones personales realizadas en el ejercicio del cargo". Ver nota 52.

58 BernasChina (1958), p. 283, habla de delitos políticos "por la trascendencia política que trae consigo su comisión"; GuerRa (1929), pp. 334-335, habla de "delitos de trascendencia pública".

${ }^{59}$ Esta amplitud se registra en tres puntos, por lo que cabe atribuirlo a una intención consciente del constituyente. El primer registro de la amplitud de las causales es el texto del artículo $53 \mathrm{~N}^{0} 1$ inciso $1^{\circ}$ de la Constitución, que califica la conducta ilícita indistintamente como delito, infracción o abuso de poder. El segundo registro es el conjunto de causales que no especifican una conducta material, como comprometer el honor de la nación o incurrir en notable abandono de deberes. El tercer registro es la independencia de las conductas delictivas típicas ( $v$. gr. traición, malversación de fondos públicos, etc.) respecto de su regulación legal (ver nota 48). La amplitud de las causales garantiza un espacio de deliberación amplio, que se ajusta mejor a la dinámica del Congreso. Bronfman et al. (2013), pp. 234-235, advierte la inevitable nota política que acompaña el estudio de estas causales por parte de las Cámaras. Se entiende que hay causales que ofrecen un margen más amplio que otras. Ver nota 112.

${ }^{60}$ Ver notas 104 y ss.
} 
fisonomía de la acusación constitucional transformándola en un resorte de la estructura de los poderes políticos, la que introdujo esta particularidad ${ }^{61}$. En el contexto de la época, el cambio debe interpretarse dentro de la tendencia por ampliar la fuerza política del Congreso frente al Ejecutivo, y no al revés. Aunque desde esta perspectiva, la reforma podría juzgarse como un retroceso, pues antes el poder del Congreso alcanzaba para caracterizar el delito y determinar la pena aplicable, en realidad era un poder prácticamente anulado por su propia amplitud ${ }^{62}$. Con la reforma, el poder del Congreso disminuyó en el texto constitucional, pero se hizo operativo. La forma de jurado garantiza al Congreso el margen de discrecionalidad que necesita para actuar como un eficaz contrapeso político del Ejecutivo ${ }^{63}$.

Las sanciones aplicables. En general, la naturaleza y alcance de las sanciones se justifican, al menos parcialmente, en su aptitud para prevenir nuevas amenazas al bien protegido o para reparar los daños causados al bien protegido. Desde esta perspectiva, podríamos deducir que la acusación constitucional busca proteger la confianza pública depositada en algunas autoridades especialmente relevantes para la marcha de los negocios públicos ${ }^{64}$. Las sanciones previstas para la acusación constitucional estarían dirigidas a terminar con la causa del daño, destituyendo al funcionario responsable, y a prevenir daños en el futuro, inhabilitándolo por cinco años para ejercer

\footnotetext{
${ }^{61}$ Ver notas 39 y 58.

62 En el Informe elaborado por la Comisión de Constitución de la Cámara de Diputados, que determinó la modificación del artículo 98 de la Constitución de 1833 e introdujo el jurado, consta cómo el factor político de la acusación constitucional fue determinante en el trueque que operó entre las amplias facultades para caracterizar el delito y determinar la pena y el decidir como jurado la inocencia o culpabilidad exclusivamente. HuneEus (1891a), pp. 192-193.

${ }^{63}$ Huneeus (1891b), pp. 153-154: "El procedimiento a que deben sujetarse es el de jurado; pero no son Jurados en realidad, desde que no se constituyen ni se renuevan en la forma que es propia y característica de esa institución". CORRAL (2015), pp. 327-329 apostilla que resolver como jurado no es sinónimo de "discrecionalidad": los senadores deben juzgar conforme al mérito del proceso. Si esto significa exigir algo más que una justificación razonada de la decisión, entonces no podemos estar de acuerdo: si el Senado no actúa como tribunal de justicia, ¿por qué había de sujetarse a los estándares propios de estos órganos?

${ }^{64}$ SChweitzer (1972), pp. 71-72, entiende la destitución del funcionario culpable como una sanción política, acorde con la naturaleza de la acusación constitucional. Pero añade que dada la gravedad de las causales de la acusación constitucional y la alta jerarquía de las autoridades acusables, que la satisfacción del interés público comprometido por la conducta del funcionario requiere, para su completa satisfacción, la pérdida de la ciudadanía activa o degradación cívica, "que impida al afectado volver a poner en peligro el honor o los intereses de la nación".
} 
funciones públicas ${ }^{65}$. La legitimidad de la sanción descansa en su finalidad política, y en la misma finalidad tiene su límite ${ }^{66}$.

\subsection{Perspectiva empírica ${ }^{67}$}

Una tercera perspectiva desde la que se descubre la finalidad prevalentemente política de la acusación constitucional es la de su mismo ejercicio. Las diferentes acusaciones que se han interpuesto a lo largo del tiempo ofrecen un material cuyo análisis permite confirmar la función que cumple la acusación constitucional e inferir su carácter y orientación política ${ }^{68}$. Al menos superficialmente, se encuentran en el texto de las acusaciones indicios de lo anterior. Por una parte, la acusación constitucional es perfilada y defendida como un mecanismo para hacer valer la responsabilidad política de las autoridades. Por otra parte, se entiende la acusación constitucional como un instrumento de conservación de los equilibrios entre el Congreso y los demás poderes estatales.

La acusación constitucional es un mecanismo de control político que se hace operativo exigiendo la responsabilidad política de ciertos funcionarios. En un estado de derecho todos son responsables. Pero hay distintos regímenes de responsabilidad. Típicamente se distingue la responsabilidad jurídica (civil-criminal), administrativa y política. La acusación constitucional es un mecanismo para hacer exigible la responsabilidad política ${ }^{69}$. Simultáneamente,

${ }^{65}$ Bronfman et al. (2013), p. 343: "Desde el punto de vista de sus fines, la acusación constitucional satisface los propósitos de protección del interés nacional con el alejamiento del funcionario declarado culpable". En el mismo sentido, HuneEus (1890), pp. 258-259.

${ }^{66}$ Bronfman et al. (2013), p. 344: "Con estos efectos se agotan los fines del juicio constitucional e ir más allá sería atribuirle objetivos que escapan al campo de lo político, para entrar en el área de lo judicial". El hecho de que sanciones análogas puedan hacerse efectivas a través de otros procedimientos y ante otros órganos significa que el Congreso no monopoliza la defensa del interés común frente a las amenazas intrínsecas al ejercicio de altos cargos públicos.

${ }^{67}$ Calificamos de empírica esta perspectiva, en atención al material de análisis, que es la praxis conocida a través de los escritos de acusación.

${ }^{68}$ Nuestro análisis está limitado a las acusaciones presentadas bajo la Constitución vigente.

${ }^{69}$ Por ejemplo, en la acusación contra los ministros de la Corte Suprema Jordán, Aburto, Zurita y Faúndez, el libelo hace suya la siguiente caracterización de las conductas perseguibles a través de la acusación constitucional: "... aquellos ilícitos que emanan de la conducta indebida de los hombres públicos, provenientes del abuso o violación de un cargo público. Esta conducta indebida posee una naturaleza que es propiamente política, ya que se relaciona sobre todo con daños causados de manera inmediata a la sociedad en el ejercicio de una función pública". Sesión 19ª (1997), p. 64. Esta caracterización guarda un evidente parecido con la definición de HAMILTON en El Federalista (ver nota 57). Otro ejemplo lo ofrece la acusación contra el intendente subrogante Iván de la Maza. En ella, los diputados acusadores entienden que la acusación constitucional es un mecanismo para 
la acusación constitucional opera como un mecanismo de control político sobre los demás poderes ${ }^{70}$.

En cuanto a lo primero, la acusación constitucional se rige por criterios políticos de oportunidad y conveniencia, principalmente ${ }^{71}$. Un ejemplo para ilustrar el punto es la acusación contra Rodrigo Hinzpeter, ministro del Interior durante el gobierno de Sebastián Piñera. Se le acusó por no haber autorizado una marcha de estudiantes por el centro de Santiago, que habría tenido como consecuencia una sarta de graves incidentes (daños materiales, lesionados, detenidos). Los acusadores reconocieron que la del ministro fue una decisión política, es decir, "[fruto de] una potestad discrecional, porque su ejercicio exige un juicio de oportunidad y prudencia por parte de la autoridad de gobierno". También reconocieron que dicha decisión está sujeta al control jurisdiccional de los tribunales de justicia. Pero al acusar advierten que ninguna de las dos circunstancias inhibe el control que sobre dicha decisión pueda ejercer el Congreso, porque la acusación constitucional es precisamente el mecanismo idóneo para hacerlo ${ }^{72}$. Así, los acusadores juzgaron la decisión y concluyeron que "el ejercicio por el Ministro de sus potestades

hacer exigible la responsabilidad de "quienes tienen a su cargo la gestión del bien común en la administración de los negocios públicos", los que han de "responder a la comunidad de los gobernados, de sus aciertos y desaciertos". Sesión 34a , p. 112. En la acusación contra Ricardo Lagos cuando era ministro de Obras Públicas, los diputados advierten que persiguen "exigir las responsabilidades políticas involucradas". Sesión $4^{a}$ (1998), p. 70. En la acusación contra el ministro de la Corte Suprema Correa, se precisa que la Constitución "no se limita a establecer mecanismos para hacer efectiva la responsabilidad jurídica del infractor o del que abusa del poder, sino también permite perseguir su responsabilidad política". Sesión $30^{a}$ (2000), p. 75. En la acusación contra los ministros Foxley y Hales, los acusadores afirmaron que "a través de esta acción (...) debemos hacer efectiva la responsabilidad política específica de los Ministros de Estado por causales jurídicamente tipificadas". Sesión $3^{a}$ (1994), p. 276. La acusación contra el general Pinochet repite que "la acusación busca acreditar la responsabilidad política, no la penal". Sesión 1ª (1998), p. 29.

${ }^{70}$ Esta idea, que se repite, se encuentra, por ejemplo, en la acusación contra Harald Beyer, sesión $6^{a}$ (2013), p. 45: el Congreso practica un control político a través de la acusación constitucional. En la acusación contra los ministros Kokisch, Ortiz y Rodríguez se precisa que "la acusación es un mecanismo excepcional de control". Sesión 9a (2005), p. 48.

${ }^{71}$ Que la responsabilidad que se persigue con la acusación constitucional sea política significa que, aun cuando la actuación u omisión que se reprocha se configure gracias al patrón de normas jurídicas legales y constitucionales, los criterios con que se valoran los hechos apuntan "a determinar o a criticar la conveniencia, la oportunidad, las ventajas o desventajas de una determinada medida del agente público, como también las consecuencias que una actuación o una abstención traen consigo". Sesión 14 ${ }^{\mathrm{a}}$ (1997), p. 54. Por ejemplo, la acusación contra el ministro Luis Correa Bulo precisa que la responsabilidad que se persigue a través de la acusación constitucional "apunta a determinar o criticar la conveniencia o no de una actuación del órgano público".

${ }^{72}$ Sesión $67^{\mathrm{a}}(2011)$, p. 38: "... la acusación constitucional es el modo de control aplicable [a] decisiones políticas que constituyen abusos de poder en los términos establecidos por la Constitución". 
discrecionales para preservar el orden público y la seguridad pública interior fue irresponsable e inoportuno"73.

En cuanto a lo segundo, la acusación constitucional actúa como uno de los resortes que conservan el equilibrio entre los distintos poderes estatales. Así lo puntualiza, por ejemplo, la acusación contra los ministros de la Corte Suprema Ortiz, Zurita, Navas y Álvarez. Frente a la objeción de que el Congreso estaría infringiendo el principio de separación de los poderes, los acusadores respondieron que la acusación no desconoce tal principio, sino que consiste en "el ejercicio de una facultad constitucional de contrapeso" ${ }^{74}$. En un sentido parecido, el escrito acusatorio contra Pinochet aclaró que "[la] acusación constitucional se inserta dentro de los mecanismos de controles recíprocos atribuidos por la Carta a los distintos órganos del Estado. En este sentido, es un mecanismo destinado a controlar el ejercicio del poder por parte de altas autoridades del Estado, a fin de evitar abusos y de impedir el exceso en el uso de las potestades" ${ }^{\prime 75}$.

La práctica de la acusación constitucional estaría demostrando que esta sirve un doble propósito político: al tiempo que funciona para hacer valer la responsabilidad política de altos funcionarios, opera como medio de control político de los otros poderes del Estado.

\section{El Congreso: intérprete supremo de la Constitución}

La tesis de este trabajo consiste en que el Congreso actúa como un intérprete supremo de la Constitución a través de la acusación constitucional, erigiéndose, por lo tanto, en un guardián político de la supremacía constitucional. En la sección anterior hemos desarrollado las razones que permiten afirmar la naturaleza eminentemente política de la acusación constitucional, en cuanto instrumento de garantía de la supremacía de la Constitución. En esta sección se desarrollarán las razones para sostener que, precisamente gracias a la acusación constitucional y dentro de su ámbito específico, el Congreso se posiciona como intérprete final de la Constitución.

\footnotetext{
${ }^{73}$ Sesión $67^{\mathrm{a}}$ (2011), p. 41. Algo equivalente se dio en la acusación contra Harald Beyer, en que la gravedad de los hechos queda al descubierto a la luz del principio de oportunidad.

${ }^{74}$ La misma idea en la acusación contra Cereceda: "la acusación [constitucional] (...) constituye sólo un factor de contrapeso con respecto a múltiples facultades directas o indirectas de dichos Magistrados, que afectan al Parlamento", p. 366. [Citamos del libro de Martínez y Rivero (2004), porque no hemos podido encontrar el texto de la acusación en otra parte. Correspondería a la sesión 31ª (1992), pp. 2788 y ss.].

${ }^{75}$ Sesión $1^{\text {a }}$ (1998), p. 28.
} 


\subsection{Acusación constitucional y posición del Congreso en la CENC}

La discusión habida en el seno de la CENC ilustra bien el significado de la acusación constitucional en relación con la posición del Congreso como intérprete de la Constitución. Esto, sin embargo, se infiere de una materia relacionada con aquella pero distinta, que es el lugar de la acusación constitucional dentro de un régimen presidencial ${ }^{76}$. Lo que ocupó la atención de la CENC cuando se discutió sobre las atribuciones del Congreso y cada una de sus ramas fue cómo establecer mecanismos de fiscalización y control eficaces sobre el Ejecutivo sin menoscabar el carácter marcadamente presidencial del régimen político. Ahora bien, este problema presupone que la fiscalización y control deben radicar en un órgano ajeno al Ejecutivo para ser eficaces. Puede decirse que el subsuelo de la discusión habida en las varias sesiones en que se abordó el tema lo constituye la tensión entre presidencialismo y parlamentarismo, que tiene una de sus expresiones particulares en la naturaleza, alcance y efectos de la acusación constitucional. Los distintos puntos debatidos sobre la acusación constitucional revelan que los comisionados eran conscientes del carácter definitivo de las interpretaciones hechas a través de dicho mecanismo; en último término, era un problema acerca de quién tenía la palabra final. En este sentido, quizá lo más ilustrativo sea la controversia acerca de la responsabilidad de los ministros de Estado. Mucho se discutió sobre los alcances de la fiscalización política de los actos de la Administración por la Cámara de Diputados y sobre la naturaleza de la responsabilidad exigible a través de la acusación constitucional. La cuestión debatida era cómo encajar estas atribuciones típicas del parlamentarismo en un régimen de cuño fuertemente presidencial. La solución propuesta, aunque difícil de sintetizar por las imprecisiones en que incurren los mismos comisionados, podría resumirse en que la fiscalización política no acarrearía ningún tipo de responsabilidad y que la acusación constitucional solo haría efectiva una responsabilidad jurídica, nunca política ${ }^{77}$. Esta solución puede

\footnotetext{
${ }^{76}$ Sesiones $340^{\mathrm{a}}, 341^{\mathrm{a}}, 346^{\mathrm{a}}, 353^{\mathrm{a}}, 354^{\mathrm{a}}$ y $417^{\mathrm{a}}$.

${ }_{77}$ El de garantizar la irresponsabilidad política de los ministros de Estado es un verdadero afán de la CENC, particularmente de la comisionada Bulnes, quien ve una total incompatibilidad entre responsabilidad política de los ministros de Estado y régimen presidencial, como puede comprobarse, por ejemplo, en sesión $340^{a}$, p. 2039, y sesión $341^{\text {a }}$, p. 2064. La posición adoptada por la CENC en este punto refleja menos la realidad de las cosas y más la decisión de resguardar el régimen presidencial, rechazando, por lo tanto, hasta la sombra de una responsabilidad política exigible por el Congreso. El intento, sin embargo, resulta boicoteado por las vacilaciones de la propia CENC al enfrentar supuestos diversos, como por ejemplo, al discutirse qué órgano debía decidir la acusación constitucional: se optó por el Senado porque otro órgano (v. gr. el Tribunal Constitucional) habría sido afectado por la carga política del instrumento. Sesión 354a , pp. 2242 y ss. Al final, la cuestión
} 
entenderse como una restringida concesión al equilibrio que debe existir entre el Congreso y el Ejecutivo, lo cual implica reconocerle al Congreso un ámbito en el cual sus definiciones son inmodificables. Los comisionados tenían perfectamente claro el potencial expansivo de las causales para acusar constitucionalmente a un ministro, en particular aquellas causales que podían calificarse como políticas ${ }^{78}$. Entendemos que la insistencia con que se afirmó la naturaleza jurídica de la responsabilidad perseguida a través de la acusación constitucional responde a la necesidad de acotar los alcances de este instrumento y adecuarlo mejor a las exigencias de un régimen presidencial. Y el interés por limitar los alcances de la acusación constitucional restringiendo sus efectos al ámbito de lo jurídico descubre, en el fondo, la convicción de que las decisiones adoptadas por el Congreso tienen un valor definitivo. Esto se repite en el contexto de las relaciones entre el Congreso y el Poder Judicial. En efecto, cuando se discutió el alcance de la causal notable abandono de deberes, aplicable a los magistrados de los tribunales ordinarios de justicia, se dejó constancia de que ella no autorizaba al Congreso en ningún caso a revisar los contenidos y fundamentos de las sentencias judiciales. Lo contrario sería equivalente a colocar un órgano político por sobre la Corte Suprema ${ }^{79}$. Sin embargo, Guzmán hizo ver la fragilidad de esta indicación al señalar que nada impediría al Congreso juzgar políticamente a los jueces por sus fallos si es que se reunían las mayorías necesarias ${ }^{80}$. En otras palabras, la interpretación que el Congreso decida hacer de la causal notable abandono de deberes es definitiva.

\subsection{Acusación constitucional y cosa juzgada}

Como complemento del análisis anterior puede añadirse una reflexión enfocada ahora sobre la naturaleza y el efecto de la decisión del Senado, con el propósito de reafirmar el carácter definitivo del veredicto y de la interpretación

\footnotetext{
es puramente nominal, porque el nombre de la responsabilidad que engendra la acusación constitucional deja intacto lo que el Congreso puede hacer a través de ella.

${ }^{78}$ Esta clasificación de las causales habría sido propuesta por el comisionado Diez y adoptada por el comisionado Guzmán. Sesión $346^{a}$, p. 2119, y sesión 353a , p. 2238. Sobre el potencial expansivo virtualmente ilimitado de las causales, el comisionado Bertelsen lo ilustró con el concepto seguridad nacional: al ser esta un elemento integrante del bien común, "está presente en toda acción de Gobierno, de tal modo que cualquier política, sea económica, de colonización, laboral, educación, etcétera, puede comprometer la seguridad de la nación y ser motivo de acusación constitucional contra un Ministro de Estado". Sesión 353ª p. 2238.

${ }^{79}$ Comisionado Ortúzar, sesión $417^{\text {a }}$, p. 3639.

${ }^{80}$ Sesión $417^{a}$, pp. 3638 y 3640.
} 
de la Constitución en que este se apoya. En la literatura nacional sobre la acusación constitucional, este punto apenas se discute o se desarrolla, probablemente porque se lo asume como una premisa de la institución ${ }^{81}$. De hecho, resulta fácil entrever en el trasfondo de otros aspectos de la acusación constitucional, este del carácter definitivo de la decisión del Senado ${ }^{82}$. Entre aquellos pocos autores que tratan explícitamente sobre la materia, hay algunos que para explicar la condición permanente de la decisión del Senado (veredicto e interpretación) recurren a una categoría típicamente procesal, la cosa juzgada ${ }^{83}$. Es el caso de Martínez y Rivero, por ejemplo, que para explicar la "inimpugnabilidad e inmutabilidad" de la decisión del Senado respecto de futuras acusaciones o de los tribunales ordinarios, afirman que "el fallo del Senado (...) produce efecto de cosa juzgada sustancial y formal a la vez" ${ }^{\prime 4}$. En general, esta manera de enfocar la cuestión de la naturaleza y efecto de las decisiones del Senado se encuadra de lleno en el problema del margen de discrecionalidad de los tribunales ordinarios al conocer los casos que han sido ya resueltos por el Congreso ${ }^{85}$. Esta última cuestión nos interesa solo de manera indirecta, en cuanto da por descontado que los tribunales no tienen competencia alguna para revisar y enmendar la interpretación y la decisión tomada por el Congreso ${ }^{86}$.

\subsection{Acusación constitucional y tribunales de justicia: el caso Cereceda}

Un caso bastante excepcional que confirma el carácter definitivo de la interpretación del Congreso es la sentencia de la Corte de Apelaciones de

\footnotetext{
81 Pienso que este sería el caso de quienes sostienen que el Congreso actúa como un tribunal de justicia, Huneeus (1890), p. 262; cumple funciones judiciales, TAPIA (1993), pp. 121-128, o ejerce un poder jurisdiccional, Colombo (2004), pp. 59-62.

82 Por ejemplo, la discusión acerca de la naturaleza de la responsabilidad exigible a través de la acusación constitucional, o lo que significa que el Senado resuelva como jurado, se justifican en último término porque los resultados del proceso son inmodificables.

83 Varas (2014), p. 85; Colombo (1968); Guerra (1929), p. 251.

${ }^{84}$ Martínez y Rivero (2004), p. 140. En el mismo sentido entendemos a Nogueira (2013), p. 249, cuando afirma que "la decisión del Senado tiene el carácter de sentencia definitiva sobre la materia".

85 Una síntesis sobre las distintas posiciones en esta materia: Bronfman et al. (2013), pp. 344-346; MARTíNez y Rivero (2004), pp. 137-139.

${ }^{86}$ En el contexto de dicha discusión, la cuestión debatida no es si acaso los tribunales de justicia pueden entrar a calificar la valoración de los hechos y la interpretación del derecho realizadas por el Congreso, con el fin de aprobar o rechazar la declaración de culpabilidad o inocencia. Lo que allí se discute es el grado de vinculación que dicha declaración y los antecedentes en los que se apoya tienen sobre los jueces Ilamados a determinar la responsabilidad civil o criminal de las personas acusadas constitucionalmente.
} 
Valparaíso que conoció el recurso de protección interpuesto en favor del exministro de la Corte Suprema Hernán Cereceda. A través de esta acción judicial dirigida contra el Congreso Nacional se demandó la nulidad de la acusación constitucional por la que se lo destituyó de su magistratura y de su cátedra universitaria ${ }^{87}$. A primera vista, esta sentencia podría parecer un contraejemplo, porque en ella la Corte afirmó su competencia para conocer y juzgar las actuaciones del Congreso, atreviéndose incluso a dictar orden de no innovar ${ }^{88}$. Esto, en la práctica, viene a significar que, al menos, los tribunales superiores de justicia pueden enmendar la interpretación que el Congreso hace de la Constitución a través de la acusación constitucional. Sin embargo, la misma sentencia sostiene precisamente lo opuesto cuando debe pronunciarse acerca de la arbitrariedad de la decisión del Senado. Los recurrentes habían alegado que la decisión recurrida era arbitraria porque, siendo cuatro los acusados constitucionalmente por el mismo hecho y la misma causal, declaró culpable a Cereceda e inocente a los otros tres. La Corte reconoció que, efectivamente, el Senado incurrió en una diferencia arbitraria que condujo a un resultado injusto, al dividir la acusación y condenar a uno y absolver a tres ${ }^{89}$. No obstante lo anterior, dijo la Corte, la alegación debe rechazarse porque el Senado, decidiendo una acusación constitucional, está autorizado por la Constitución "para resolver a su libre arbitrio"90. En un sentido equivalente se pronunció cuando hubo de resolver si acaso uno de los hechos imputados al acusado, i. e. el haberse demorado en la dictación de una sentencia, tenía la entidad para constituir notable abandono de deberes. Dijo a este propósito que a la Corte no le correspondía "emitir juicio alguno, pues el juzgamiento de tal hecho (...) cae bajo el imperio de las facultades exclusivas y excluyentes" del Senado ${ }^{91}$. En otras palabras, la Corte se declaró incompetente sin decirlo. Comentando esta sentencia, Fernando Atria plantea correctamente el meollo del problema que subyace al caso: se trata de definir quién tiene la última

\footnotetext{
${ }^{87} 6$ de abril de 1993, rol № 20.688. Finalmente, la parte recurrente se desistió de la apelación.

${ }_{88} \mathrm{Al}$ preguntarse si acaso el recurso de protección era procedente contra actos del Congreso, la Corte llegó a la conclusión, luego de una serie de argumentos, de que el recurso tenía "una amplitud ilimitada (...) en cuanto al agente causante del acto u omisión arbitrario o ilegal". Considerando $8^{\circ} \mathrm{H}$.

${ }^{89}$ Considerando $27^{\circ}$.

${ }^{90}$ Considerando $28^{\circ}$. La Corte identifica esta autorización de la Constitución en la disposición que ordena al Senado resolver como jurado. Puesto que decidiendo la acusación constitucional, el Senado actúa como tribunal no letrado, "la Constitución no ha querido ni ha podido exigirle que resuelva en conciencia, entendida esta jurídicamente, sino que lo autoriza para que resuelva a su arbitrio".

${ }^{91}$ Considerando $27^{\circ}$.
} 
palabra ${ }^{92}$. La alternativa que enfrenta la Corte es si el significado definitivo de la Constitución interpretada a través de la acusación constitucional depende de los tribunales de justicia o del Congreso. La sentencia se resolvió por la segunda opción: “... autoridad alguna y bajo ningún pretexto [puede] invadir atribuciones propias de un órgano del Estado independiente en sus funciones propias, como lo es el Senado en esta materia" ${ }^{\prime \prime 3}$. Atria estima que la decisión de la Corte fue acertada ${ }^{94}$ : la acusación constitucional es una cuestión política y, en una democracia, parece más adecuado que cuestiones de esta naturaleza las resuelva el Congreso ${ }^{95}$. La sentencia no va más allá de las razones recién expuestas para justificar su incompetencia respecto de los resultados de la acusación constitucional, pero en cambio refleja con claridad el reconocimiento de un ámbito de la interpretación constitucional que le está vedado. Ese ámbito es el de la acusación constitucional ${ }^{96}$.

\subsection{Inexistencia de mecanismos para enmendar la decisión del Senado}

Otra prueba que puede invocarse para apoyar la tesis de que el Congreso interpreta definitivamente la Constitución a través de la acusación constitucional es la inexistencia de órgano, procedimiento o recurso alguno que pueda servir para revisar y corregir lo resuelto por el Senado. En este contexto, es interesante un antecedente histórico. Originalmente, la Constitución de 1833 en su artículo 98 decía que contra la sentencia pronunciada por el Senado

\footnotetext{
92 Atria (1993), p. 235.

${ }_{93}$ Considerando $27^{\circ}$.

94 ATRIA (1993), p. 234: “... a pesar de lo chocante que pueda parecer (...) debe celebrarse que (...) la Corte haya reconocido: hay ciertos actos que, pese a ser (o poder ser) arbitrarios, no tienen control jurisdiccional".
}

95 Espero haber interpretado correctamente a Atria, quien literalmente dice: “... parece más democrático que, en circunstancias extremas, [la última palabra] la tenga el Senado y no una sala de una Corte de Apelaciones o de la Corte Suprema. Esto es ratificado por la Constitución, que entrega al Senado la decisión de los conflictos de competencia entre los tribunales superiores de justicia y el Senado [sic] (...). Como [esta] es una cuestión política (al igual que lo es la acusación constitucional), los resuelve el Senado". AtriA (1993), p. 235. Aquí hay un error, pues de acuerdo al artículo 53 de la Constitución debería decir "las autoridades políticas o administrativas" cuando se refiere a la contraparte de los tribunales superiores de justicia.

${ }^{96}$ Cuando, en 2013, la Corte de Apelaciones de Valparaíso tuvo una nueva oportunidad para pronunciarse sobre una acusación constitucional, se rechazó el recurso porque a la Corte no le corresponde calificar la ilegalidad o arbitrariedad de la acusación constitucional. Corte de Apelaciones de Valparaíso, Harald Beyer contra H. Senado de la República, rol № 1251-2013, 19 de junio de 2013, considerando 5 ${ }^{\circ}$ confirmada por la Corte Suprema, rol № 4295-2013, 9 de julio de 2013. 
"no habrá apelación ni recurso alguno"97. Lo más plausible es que esta disposición reflejara su inspiración inglesa, según la cual el Parlamento era la única instancia judicial para conocer el impeachment. Si bien la reforma constitucional de 1874 eliminó esta disposición, ello no debe entenderse como si entonces las decisiones del Senado pasaran a ser recurribles. El espíritu de la reforma fue aumentar el protagonismo del Congreso frente al presidencialismo dominante de las últimas décadas ${ }^{98}$. En este contexto, la acusación constitucional experimentó una transformación en servicio del Congreso, como contrapeso político del Presidente. Al discutirse las características de esta institución en la que sería la Constitución de 1925, se confirmó lo anterior: la acusación constitucional se entendió fundamentalmente como una atribución del Congreso que relativiza el poder del Presidente de la República ${ }^{99}$. La CENC concibió la acusación constitucional en términos esencialmente idénticos y la Constitución de 1980 no introdujo innovación alguna en este aspecto ${ }^{100}$. Esta ausencia de medios de control sobre el proceso y resultado de la acusación constitucional, aparte de los que disponga la corporación internamente, posiciona al Congreso como intérprete final de la Constitución, dentro del ámbito específico de la acusación constitucional. Quizá sea este el marco que mejor explica la significación del adjetivo "exclusiva" del artículo 52 de la Constitución, que califica tanto la atribución de la Cámara Baja para acusar como la del Senado para decidir la acusación. Para Zúñiga, la exclusividad implica que "le está vedado a otro órgano del Estado ejercer la función jurisdiccional política, avocarse a sus asuntos, revisar los fundamentos de sus decisiones o acuerdos" ${ }^{\prime 101}$.

\subsection{La configuración del Senado como jurado}

Hay otro argumento favorable a la tesis de este trabajo que nace de la configuración del Senado como jurado para decidir las acusaciones constitucionales. En el contexto del profundo cambio que el régimen político estaba experimentando cuando se reformó la Constitución en 1874, ¿cómo debe interpretarse la novedad que significó disponer que el Senado resolviera como jurado las acusaciones constitucionales? Todo indica que la nueva disposición

\footnotetext{
${ }^{97}$ Artículo 98.

${ }^{98}$ Ver notas 39 y 43.

99 ACtAS (1925), pp. 72 y ss.

100 Ver nota 78 y ss.

101 ZúNIIGA (1993), p. 722. En este mismo sentido debe entenderse la interpretación del vocablo que hizo la Corte de Apelaciones de Valparaíso en la sentencia Cereceda. Ver nota 93.
} 
refleja la voluntad del constituyente de garantizar al Congreso un espacio que dé cabida a consideraciones políticas en la apreciación de las causales que pueden motivar una acusación constitucional eliminando, al mismo tiempo, facultades que corresponden propiamente a jueces profesionales ${ }^{102}$. Al fin y al cabo, el espíritu de la reforma era aumentar el protagonismo político del Congreso y la figura del jurado se avenía bien con ese espíritu ${ }^{103}$. Pero, además, la figura del jurado se corresponde adecuadamente a un proceso -el de la acusación constitucional- cuyo resultado final es una decisión que no puede ser enmendada. En esta conclusión incide en forma determinante la naturaleza eminentemente política de la acusación constitucional. Por una parte, está la necesidad de posibilitar la predominancia de las consideraciones políticas sobre las jurídicas en las deliberaciones del Senado. Esta necesidad reclama como propia una modalidad en que los distintos elementos de la decisión estén eximidos de los estándares típicos de los procesos de derecho. Por otra parte, esta clase de procesos deliberativos intencionalmente abiertos a criterios políticos conviene de modo natural a la única o última instancia, porque implican un voto de confianza en la prudencia de quienes participan en ellos. En esta línea, existe una coincidencia sugerente entre los otros dos únicos casos previstos por la Constitución para que un órgano actúe como jurado, además del Senado, decidiendo las acusaciones constitucionales. Estos dos casos son el de la Corte Suprema resolviendo las reclamaciones de nacionalidad (artículo 12) y el Tribunal Calificador de Elecciones (Tricel) en la apreciación de los hechos de las causas que le toque resolver (artículo 95 inciso $5^{\circ}$ ). La coincidencia entre estos dos casos puede servir, por analogía, para concluir que la configuración del Senado como jurado está alineada con el carácter definitivo de la interpretación de la Constitución, que hace a través de la acusación constitucional. En los dos casos mencionados, las materias tienen un innegable componente político que requieren para su mejor solución la consideración de criterios políticos ${ }^{104}$. Y en ambos casos,

102 Informe de la Comisión de Constitución de la Cámara de Diputados, presentado el 11 de junio de 1872, en HuneEus (1891), pp. 191-193.

103 Guerra (1929), p. 248.

${ }^{104}$ En el caso de las materias que conoce el Tricel, es elocuente la intervención de Francisco Vidal en la discusión sobre la integración del Tribunal en la Constitución de 1925: “... considera que es necesaria la presencia de algunos políticos en el Tribunal, porque los juicios sobre calificaciones [de elecciones] no son juicios jurídicos Ilanos, sino que tienen carácter político y jurídico". Actas (1925), p. 364. En el caso de la reclamación de nacionalidad, valga la intervención del comisionado Evans en la CENC cuando, defendiendo la conveniencia de que la Corte Suprema conociera de los casos sobre rehabilitación de la nacionalidad, dijo: "Los jueces han dado muestras de buen criterio en la consideración de juicios políticos, ya que tienen nada menos que la facultad de desaforar a 
los órganos Ilamados a resolver lo hacen en única instancia ${ }^{105}$. Esta atribución entrañaría, por tanto, la confianza en la prudencia del órgano a que se le entrega la decisión final. Una última observación que refuerza la conclusión anterior a propósito de un problema planteado por los autores del libro Derecho parlamentario chileno. Estos se preguntan cuál sería la sanción en caso de que el Senado no actuara como jurado infringiendo, por ejemplo, la prohibición del artículo 32 de la Ley Orgánica Constitucional de Partidos Políticos ${ }^{106}$. Aunque la respuesta que dan se limita a constatar que "no existe un precepto claro de donde asirse para revertir, o al menos enervar, una acción constitucional basada únicamente en consideraciones partidistas"107, lo cierto es que el Derecho no prevé sanción alguna que pueda alterar el resultado de la acusación ${ }^{108}$. A nuestro juicio, esto no es una omisión reprochable, sino confirmación de la posición del Congreso como garante último de la Constitución, en el ámbito de la acusación constitucional.

\subsection{El margen de interpretación}

La configuración del Senado como jurado está íntimamente asociada a la libertad del Congreso para interpretar la Constitución. Esta libertad es un último aspecto que analizaremos desde la perspectiva del Congreso en cuanto intérprete definitivo de la Constitución. Diremos que son las aprensiones que despierta el amplio grado de libertad del Congreso para interpretar la Constitución -con las consecuencias que ello implica- la prueba de que los resultados de esa interpretación son definitivos, la última palabra. Pero antes

los parlamentarios, en donde evidentemente deben emitir un juicio de naturaleza jurídico-político. Incluso se le ha dado a la Corte Suprema la facultad de pronunciarse como jurado en los casos en que se cancela la carta de nacionalización". Sesión 71ª, p. 484.

105 El artículo 13 de la Ley Orgánica Constitucional del Tricel dispone que "[c]ontra las resoluciones del Tribunal no procederá recurso alguno". Respecto de la resolución que resuelve la reclamación de nacionalidad, cabría únicamente el recurso de reposición ante la misma Corte, de acuerdo al artículo 276 inciso $4^{\circ}$ del Código de Procedimiento Civil. Ni la Constitución ni el auto acordado que reglamenta esta reclamación establecen otra cosa.

106 Bronfman et al. (2013), p. 341. El artículo 32 de la ley № 18.603 dispone: "En ningún caso podrán los partidos políticos dar órdenes de votación a sus Senadores y Diputados ni realizar recomendaciones en los casos en que el Senado esté llamado a obrar como jurado".

107 Bronfman et al. (2013), p. 341. Los autores piensan que esto es grave, especialmente desde la perspectiva del debido proceso. Sugieren que el artículo $7^{\circ}$ de la Constitución podría ser interpretado en forma tal que sirviera para atajar los abusos. Nosotros, en cambio, estimamos que esto es simplemente una condición o consecuencia, como se prefiera, de la interpretación definitiva de la Constitución.

108 Esto no significa que los parlamentarios estén exentos de responsabilidad por haber procedido en infracción a la ley. 
de llegar a esto, conviene caracterizar la amplitud de que goza el Congreso como intérprete de la Constitución. En primer lugar, lo obvio: el Congreso no está vinculado por la ley. Esto no lo decimos respecto de aquellas causales que carecen de tipificación legal exclusivamente, sino de todas. Aunque la práctica enseñe que las acusaciones, en general, desarrollan argumentos basados en la legislación, ello obedece a la necesidad de persuadir a la audiencia. Es propio de un jurado apreciar los antecedentes en conciencia, lo cual implica que cada uno de sus miembros les asigna a los hechos y al derecho el valor que le dicta su leal saber y entender, a menos que se diga lo contrario ${ }^{109}$. Esta circunstancia, que en principio está circunscrita al Senado, se proyecta inevitablemente hacia la etapa de la acusación. En segundo lugar, y por la misma razón que se acaba de exponer, el Congreso no está vinculado por el precedente de sus decisiones. En tercer lugar, la mayoría de las causales para acusar constitucionalmente son extremadamente amplias ${ }^{110}$. Esta característica puede invocarse como una prueba de la libertad que la Constitución deja al Congreso para que la interprete. Dentro del campo abierto por las fórmulas empleadas para las diferentes causales, el Congreso es soberano en la determinación de sus contenidos. Como decíamos al comienzo de esta sección, la posición del Congreso como garante último de la supremacía constitucional despierta aprensiones. En efecto, las tres características recién anotadas han dado pie a una serie de consideraciones que, en último término, se explican como un esfuerzo por contener los efectos negativos inherentes a la posición de garante final de la Constitución, que ocupa el Congreso cuando acusa constitucionalmente ${ }^{111}$.

\subsection{Acusación constitucional y jurisdicción internacional}

Hay que referirse a la situación creada por la posición de la Corte Interamericana de Derechos Humanos (Corte IDH), en relación con la

109 En el caso del Tricel, por ejemplo, la Constitución expresamente limita la actuación como jurado a la apreciación de los hechos, debiendo sentenciar "con arreglo a derecho".

110 Se podría aquí objetar que esta característica es redundante, porque si la ley no es vinculante, todas las causales son igual de amplias. Sin embargo, esto implica desconocer las restricciones impuestas por el campo semántico de las diferentes causales. Los hechos que pueden comprenderse dentro del campo de términos como traición o cohecho, por ejemplo, son menos que los comprendidos por fórmulas como infracción de las leyes o notable abandono de deberes.

111 A modo ilustrativo, podrían señalarse entre esas consideraciones: la obligación del Congreso de observar el principio del debido proceso, Díaz de VALdés (2013), pp. 109-117; el efecto vinculante de las sentencias de la Corte Interamericana de Derechos Humanos sobre las decisiones del Congreso, Nogueira (2013); que al fallar como jurado, los senadores deben estarse al mérito del proceso, CORRAL (2015). 
supremacía interpretativa que tiene el Congreso cuando resuelve una acusación constitucional. ¿Podría la Corte IDH sancionar a Chile por los resultados de una acusación constitucional, pronunciándose sobre cuestiones de forma y fondo del proceso? ${ }^{112}$.

Existe una sentencia de la Corte IDH sobre la materia. En ella se resolvió la denuncia hecha por tres magistrados del Tribunal Constitucional peruano en contra del Estado peruano por las infracciones a la Convención Americana de Derechos Humanos en que el Congreso habría incurrido durante la acusación constitucional que culminó con su destitución ${ }^{113}$. La Corte IDH afirmó su competencia para conocer del caso, sobre la base de que es "ilícita, toda forma de ejercicio del poder público que viole los derechos reconocidos por la Convención"114. La protección de los derechos humanos habilita a la Corte IDH para indagar la forma como se llevó adelante el proceso de acusación constitucional. La Corte IDH asumió que el Congreso ejerce funciones jurisdiccionales al tramitar y resolver una acusación constitucional, por lo que le son plenamente exigibles las garantías del debido proceso ${ }^{115}$. Entre ellas, la Corte IDH destacó las cualidades del órgano juzgador, que debe ser "competente, independiente e imparcial"116. Atendidas las circunstancias acreditadas en el juicio, la Corte IDH estimó que el Congreso infringió el derecho al debido proceso, entre otros motivos, porque no actuó como juez imparcial ${ }^{117}$. Además, aclaró que la acusación constitucional es un procedimiento sometido "a normas legales que deben ser puntualmente observadas", por lo que bien pueden "ser objeto de una acción o recurso judiciales en lo que concierne al debido proceso legal",

\footnotetext{
112 Eventualmente, Chile tendrá que adoptar una postura frente a esta cuestión, a raíz de la denuncia interpuesta por Yasna Provoste. Ministra de Educación entre 2006-2008, destituida por el Congreso al declararla culpable de la acusación formulada por la Cámara de Diputados, denunció al Estado de Chile ante la Comisión Interamericana de Derechos Humanos.

113 Corte IDH, Caso del Tribunal Constitucional vs. Perú, 31 de enero de 2001, serie C № 71.

114 Párrafo 69.

115 Párrafo 71.

116 Párrafo 77.

117 Párrafo 84: "De conformidad con los criterios establecidos por este Tribunal, es evidente que el procedimiento de juicio político al cual fueron sometidos los magistrados destituidos no aseguró a éstos las garantías del debido proceso legal y no se cumplió con el requisito de la imparcialidad del juzgador. Además, la Corte observa que, en las circunstancias del caso concreto, el Poder Legislativo no reunió las condiciones necesarias de independencia e imparcialidad para realizar el juicio político contra los tres magistrados del Tribunal Constitucional". Díaz de VALdés (2013), pp. 114-115, comparte el criterio de la Corte IDH en este punto.
} 
haciendo la salvedad de que dicho "control no implica valoración alguna sobre actos de carácter estrictamente político atribuidos por la Constitución al Poder Legislativo"118.

Con esta sentencia, la Corte IDH vacía completamente la acusación constitucional de su contenido político y, con ello, desarticula el mecanismo de pesos y contrapesos que mantiene el equilibrio entre los poderes del Estado. Este proceso de vaciado se produce a través de dos compuertas abiertas por la Corte IDH con su sentencia. La primera es la competencia de la misma Corte IDH para juzgar si el proceso de acusación constitucional es respetuoso de los derechos humanos. La segunda es la competencia del Poder Judicial para juzgar esa misma materia ${ }^{119}$. Al declarar la acusación constitucional susceptible de este doble control jurisdiccional, la dimensión política del proceso queda subordinada a la dimensión jurídica, y como consecuencia, el Congreso queda subordinado al poder de los jueces, estatales e internacionales. En un esquema como este, la salvedad hecha en el párrafo 94, i. e. la intangibilidad de los actos políticos, simplemente carece de significado práctico. Y la declaración del párrafo 63, en cuanto a que la acusación constitucional no supone la subordinación del órgano que puede ser controlado por medio de este mecanismo, resulta no solo contradicha, sino invertida por el razonamiento de la Corte IDH $^{120}$. Las premisas en que se sustenta este fallo de la Corte IDH brotan de una concepción que sofoca lo político bajo el manto de la eficacia jurisdiccional de los derechos humanos $^{121}$. El único argumento que cabe oponer a la tesis de la Corte IDH, en el contexto de este trabajo, es el de las consecuencias que tendría para la estructura del régimen político aceptar que el Congreso está sujeto a control jurisdiccional cuando tramita y decide una acusación constitucional. La organización social estaría inclinándose entonces decididamente hacia un gobierno de los jueces.

\footnotetext{
118 Párrafo 94.

119 Párrafo 94.

120 En lo que nos interesa, dice el párrafo 63: "En un Estado de Derecho, el juicio político es una forma de control que ejerce el Poder Legislativo con respecto a los funcionarios superiores tanto del Poder Ejecutivo como de otros órganos estatales. No obstante, este control no significa que exista una relación de subordinación entre el órgano controlador -en este caso el Poder Legislativo- y el controlado -en el caso el Tribunal Constitucional-, sino que la finalidad de esta institución es someter a los altos funcionarios a un examen y decisión sobre sus actuaciones por parte de la representación popular".

121 Estas premisas son aceptadas por NogueIRA (2013), pp. 249-250.
} 


\section{Conclusión}

La garantía política de la supremacía constitucional que corresponde al Congreso como último intérprete de la Constitución, cuando resuelve una acusación constitucional, da cuenta de que la supremacía constitucional no tiene un único guardián final. Esto implica que la supremacía constitucional es una noción que excede el marco propuesto por el carácter jurídico-normativo de la Constitución. La Constitución es incorrectamente comprendida cuando se la concibe como una realidad principal o exclusivamente jurídico-normativa. Lo mismo si se la concibe como algo esencial o eminentemente político. Esta naturaleza compuesta de la Constitución es lo que justifica la existencia de varios intérpretes definitivos de su texto. Nadie puede arrogarse la exclusividad para pronunciar la última palabra acerca del significado de la Constitución, si no es dentro de un ámbito específico, determinado por la naturaleza del órgano y por los mecanismos de garantía. Esto es lo que ocurre cuando el Senado se pronuncia sobre una acusación constitucional.

\section{BiBLIOGRAFíA CITADA}

AldunAte, Eduardo (2010): "Aproximación conceptual y crítica al neoconstitucionalismo", en: Revista de Derecho, Universidad Austral de Chile (vol. 23, No 1), pp. 79-102.

ATRIA, Fernando (1993): "Comentario a la sentencia recaída sobre el caso Cereceda", en: Revista de Derecho y Humanidades (año II, Nos. 3 y 4), pp. 229-238.

ATRIA, Fernando (2000): "Revisión judicial: el sindrome de la víctima insatisfecha", en: Estudios Públicos ( $N^{\circ} 79$ ), pp. 347-402.

Bernaschina, Mario (1958): Manual de Derecho Constitucional (Santiago, Editorial Jurídica de Chile).

Blackstone, William (1795): Commentaries on the laws of England, $12^{\text {th }}$ ed. (London, Strahan and Woodfall), Vol. IV.

Bordalí, Andrés (2007): "La unidad en la interpretación jurisdiccional de los derechos fundamentales: una tarea pendiente en el derecho chileno", en: Revista Chilena de Derecho (vol. 34, № 3), pp. 517-538.

Brahm, Enrique (2007): Mariano Egaña. Derecho y política en la fundación de la república conservadora (Santiago, Centro de Estudios Bicentenario).

Bronfman, Alan (2005): "El tipo de responsabilidad perseguida en el juicio político", en: Revista de Derecho, Pontificia Universidad Católica de Valparaíso (vol. XXVI), pp. 89-117. 
Bronfman, Alan; Cordero, Eduardo y Aldunate, Eduardo (2013): Derecho parlamentario chileno: Funciones y atribuciones del Congreso Nacional (Santiago, LegalPublishing).

Bulnes, Luz (1998): "La fuerza normativa de la Constitución", en: Revista Chilena de Derecho (número especial), pp. 137-142.

CAmpos, Fernando (1963): Historia constitucional de Chile (Santiago, Editorial Jurídica de Chile).

Carbonell, Miguel (2009): [Introducción], en: Carbonell, Miguel (coord.), Neoconstitucionalismo(s), $4^{\mathrm{a}}$ ed. (Madrid, Editorial Trotta).

Carbonell, Miguel (2010): "El neoconstitucionalismo: significado y niveles de análisis", en: Carbonell, Miguel y García Jaramillo, Leonardo (eds.), El canon neoconstitucional (Madrid, Editorial Trotta), pp. 153-164.

Carreño, Gonzalo y Jaraquemada, Jorge (2010): "La fuerza vinculante de las sentencias constitucionales y el reconocimiento de derechos fundamentales. A propósito de la ley sobre regulación de la fertilidad", en: Revista Chilena de Derecho (vol. 37), pp. 405-419.

CEA, José Luis (1996): "La constitucionalización del derecho", en: Revista de Derecho Público (No 59), pp. 11-22.

CeA, José Luis (1999): El sistema constitucional de Chile: síntesis crítica (Santiago, Universidad Austral de Chile, Facultad de Ciencias Jurídicas y Sociales).

CeA, José Luis (2006): "La jurisdicción constitucional", en: Revista de Derecho de la Universidad Finnis Terrae (año X, № 10), pp. 11-19.

CEA, José Luis (2007): "Praxis del control de constitucionalidad en Chile", en: XXXVII Jornadas de Derecho Público (Valparaíso, Ediciones Universitarias de Valparaíso). Disponible en: http://www.jornadasderechopublico.ucv.cl/ponencias/PRAXIS\%20DEL\%20CONTROL\%20DE\%20 CONSTITUCIONALIDAD\%20EN\%20CHILE.pdf [visitado el 26 de mayo de 2015].

Colombo, Juan (1968): "La Jurisdicción en el Derecho chileno", en: Anales de la Facultad de Ciencias Jurídicas y Sociales [S.I.] (vol. 8, No 8). Disponible en: <http://www.cuadernosjudaicos.cl/index.php/ACJYS/article/ view/10351/10407> [visitado el 26 de mayo de 2015].

Colombo, Juan (2004): La competencia, $2^{\text {a }}$ ed. (Santiago, Editorial Jurídica de Chile).

Colombo, Juan (2005): "Las sentencias constitucionales: tipología y efectos", en: Nogueira, Humberto (coord.), Jurisdicción constitucional en 
Chile y América Latina: presente y prospectivas (Santiago, LexisNexis), pp. 263-291.

CorRal, Hernán (2014): "Constitucionalización del Derecho Civil. Reflexiones desde el sistema jurídico chileno", en: Villabelta, Carlos et al. (coord.), Derecho Civil Constitucional (Colombia, Instituto de Ciencias Jurídicas de Puebla, Editorial Mariel S.C., Universidad de la Sabana), pp. 1-16.

Corral, Hernán (2015): El derecho nuestro de cada día. Crónicas jurídicoblogueras (Santiago, Thomson Reuters).

CORREA, Raúl (2009): "Vulgarización por constitucionalización", en: FACULTAD de Derecho Universidad de Chile (edit.), Democracia y derechos fundamentales desde la filosofía política (Santiago, Editorial Jurídica de Chile), pp. 35-54.

Cristi, Renato y Ruiz-Tagle, Pablo (2014): El constitucionalismo del miedo. Propiedad, bien común y poder constituyente (Santiago, LOM Ediciones).

Díaz de Valdés, Rodrigo (2013): "Acusación constitucional y debido proceso", en: AA.VV., Congreso Nacional. Libro Homenaje al profesor Alejandro Silva Bascuñán (Santiago, Editorial Jurídica de Chile), pp. 99-118.

Domínguez, Ramón (1996): "Aspectos de la constitucionalización del Derecho Civil chileno", en: Revista de Derecho y Jurisprudencia (Tomo XCIII, № 3), pp. 107-137.

Fernández, Mario (2013): La Constitución contra sí misma (Santiago, LegalPublishing-Thomson Reuters).

FernÁNDEZ, Miguel Ángel (2001): "La fuerza normativa de la Constitución", en: Revista de Derecho Público (vol. 1, № 63), pp. 77-102.

FERNÁNDEZ, Miguel Ángel (2006): "La sentencia del Tribunal Constitucional, su eventual carácter vinculante y la inserción en las fuentes del Derecho", en: Estudios Constitucionales (año 4, № 1), pp. 125-149.

Galdames, Luis (1926): Historia de Chile. La Evolución Constitucional (Santiago, Balcells), tomo I.

García, José Francisco y Verdugo, Sergio (2013): Activismo judicial en Chile. ¿Hacia el gobierno de los jueces? (Santiago, Ediciones LyD).

García de Enterría, Eduardo (2006): La Constitución como norma y el Tribunal Constitucional, $4^{\text {a }}$ ed. (Navarra, Civitas).

Garrote, Emilio (2012): "Cosa juzgada constitucional sui generis y su efecto en las sentencias del tribunal constitucional en materia de inaplicabilidad e inconstitucionalidad", en: Estudios Constitucionales (10, № 2), pp. 391-428. 
Gerdhart, Michael J. (1996): The Federal Impeachment Process: A Constitutional and Historical Analysis (Princeton, Princeton University Press).

Guerra, José Guillermo (1929): La Constitución de 1925 (Santiago, Balcells y Co.).

Guzmán, Alejandro (2001): El Derecho Privado Constitucional de Chile (Valparaíso, Edeval).

Hamilton, Alexander; Madison, James; Jay, John (2003): The Federalist Papers (USA, Signet Classics).

Heise, Julio (1954): Historia Constitucional de Chile (Santiago, Editorial Jurídica de Chile).

Huneeus, Jorge (1890): La Constitución ante el Congreso (Santiago, Imprenta Cervantes), tomo I.

HuneEus, Jorge (1891a): La Constitución ante el Congreso (Santiago, Imprenta Cervantes), tomo II.

Huneeus, Jorge (1891b): Estudios sobre Derecho Constitucional Comparado (Santiago, Imprenta Cervantes).

Huneeus, Antonio (1933): La Constitución de 1833. Ensayo sobre nuestra historia constitucional de un siglo (Santiago, Editorial Splendid).

Kelsen, Hans (1995): Teoría General del Derecho y del Estado (trad., Eduardo García, México, UNAM).

Lastarria, José Victorino (1865): Elementos de Derecho Público Constitucional Teórico, Positivo y Político, $3^{\mathrm{a}}$ ed. (Gante) [Edición facsimilar, Kessinger Legacy Reprints].

LOVEMAN, Brian y LIRA, Elizabeth (2000): Las acusaciones constitucionales en Chile. Una perspectiva histórica (Santiago, LOM Ediciones y Flacso).

Martínez, Gutenberg y Rivero, Renée (2004): Acusaciones Constitucionales. Análisis de un caso. Una visión parlamentaria (Santiago, Editorial Jurídica de Chile).

Martínez, Sergio (1965): "La residencia en el derecho patrio chileno", en: Revista Chilena de Historia del Derecho ( $\left.N^{\circ} 4\right)$, pp. 129-207.

NAvARro, Enrique (2012): "35 años del recurso de protección: notas sobre su alcance y regulación normativa", en: Estudios Constitucionales (año $\left.10 \mathrm{~N}^{\circ} 2\right)$, pp. 617-642.

Nieto, Alejandro (1983): "Peculiaridades jurídicas de la norma constitucional", en: Revista de Administración Pública ( ${ }^{\circ}{ }^{\circ}$. 100-102, vol. I), pp. 371-415. 
Nogueira, Humberto (2005): "El control represivo concreto y abstracto de inconstitucionalidad de leyes en la reforma de las competencias del Tribunal Constitucional y los efectos de sus sentencias", en: Estudios Constitucionales (año 3, No 1), pp. 11-35.

Nogueira, Humberto (2007): "El Recurso de protección en el contexto del amparo de los derechos fundamentales latinoamericano e interamericano", en: lus et Praxis (vol. 13, № 1), pp. 75-134.

Nogueira, Humberto (2010): "La sentencia del Tribunal Constitucional en Chile: análisis y reflexiones jurídicas", en: Estudios Constitucionales (año 8, № 1), pp. 79-116.

NogueirA, Humberto (2013): "Consideraciones sobre la acusación constitucional en la carta fundamental vigente", en: AA.VV., Congreso Nacional. Libro Homenaje al profesor Alejandro Silva Bascuñán (Santiago, Editorial Jurídica de Chile), pp. 223-254.

NúÑEz, José Ignacio (2012): “Constitución, neoconstitucionalismo y lagunas jurídicas (normativas y axiológicas)", en: Estudios Constitucionales (año $\left.10, \mathrm{~N}^{\circ} 2\right)$, pp. 511-532.

NúÑEz, José Ignacio (2013): Neoconstitucionalismo y control de constitucionalidad de la ley. ¿El constitucionalismo del derecho libre? (México, Editorial Porrúa e Imdpc).

NúÑEz, Manuel (2008): "El control de la igualdad en la aplicación de la ley como factor de expansión del control concreto de constitucionalidad de las leyes", en: Sentencias Destacadas 2007 (Santiago, Instituto Libertad y Desarrollo), pp. 123-161.

NúÑEZ, Manuel (2010): "El neoconstitucionalismo y el recurso a los valores en la jurisprudencia del Tribunal Constitucional chileno", en: Revista de Derecho, Pontificia Universidad Católica de Valparaíso (vol. XXXIV), pp. 523-541.

Pfeffer, Emilio (2006): "El recurso de protección y su eficacia en la tutela de derechos constitucionales en Chile", en: Estudios Constitucionales (año 4, No 2), pp. 87-107.

Povez del VilLar, Carlos (1963): Reformas constitucionales durante el gobierno de Federico Errázuriz Zañartu, Memoria de licenciatura, Universidad Católica de Chile.

Pozzolo, Susanna (2009): "Un constitucionalismo ambiguo", en: Carbonell, Miguel (coord.), Neoconstitucionalismo(s), 4ª ed. (Madrid, Editorial Trotta), pp. 187-210. 
Roldán, Alcibíades (1913): Elementos de Derecho Constitucional de Chile (Santiago, Imprenta, Litografía i Encuadernación Barcelona).

Schmitt, Carl y Kelsen, Hans (2009): La polémica Schmitt/Kelsen sobre la justicia constitucional (Trads., Manuel Sánchez y Roberto Brie, Madrid, Tecnos).

SCHweitzer, Daniel (1972): Acusación constitucional (Santiago, Editorial Andrés Bello).

Siıva, Alejandro (2000): Tratado de Derecho Constitucional (Santiago, Editorial Jurídica de Chile), tomo VI.

SILVA, Luis Alejandro (2009): El control de constitucionalidad de los actos administrativos legales (Santiago, LegalPublishing).

SILVA, Luis Alejandro (2012): “¿Es el Tribunal Constitucional el supremo intérprete de la Constitución?", en: Revista de Derecho, Pontificia Universidad Católica de Valparaíso (vol. XXXVIII, № 1), pp. 573-616.

Story, Joseph (1858): Commentaries on the Constitution of the United States, $3^{\text {rd }}$ ed. (Boston, Little Brown and Co.) [edición facsimilar, 2001, The Lawbook Exchange, New Jersey], vol. II.

TAPIA, Jorge (1993): "Funciones y atribuciones del Parlamento entre 1960-1990", en: AA.VV., Diagnóstico Histórico jurídico del Poder Legislativo en Chile 1960-1990 (Valparaíso, CEAL), pp. 85-132.

UlLOA, Jorge (2009): Acusación constitucional y juicio político (Santiago, Editorial Jurídica de Chile).

VARAS, Paulino (2014): "Propuesta de modificación del artículo 20 de la Constitución", en: Revista de Derecho Público (número especial), pp. 85-87.

Verdugo, Sergio (2013): "La discusión democrática sobre la revisión judicial de las leyes de diseño institucional y modelos constitucionales", en: Revista Chilena de Derecho (vol. 40, № 1), pp. 181-223.

Vergara, Alejandro (1991): "La propietarización de los derechos", en: Revista de Derecho, Pontificia Universidad Católica de Valparaíso (vol. XIV), pp. 281-291.

VIAL, Leonidas (1934): El juicio político, Memoria de Prueba para optar al grado de licenciado en Ciencias Jurídicas y Sociales de la Universidad de Chile (Santiago, Talleres Gráficos San Vicente).

ZAPATA, Patricio (2008): Justicia constitucional. Teoría y práctica en el derecho chileno y comparado (Santiago, Editorial Jurídica de Chile).

ZúNílGA, Francisco (1993): "Acusación en juicio político: notas sobre la justicia política", en: Revista Chilena de Derecho (vol. 20, № 2-3), pp. 705-724. 
JURISPRUDENCIA CITADA

Harald Beyer contra H. Senado de la República: Corte de Apelaciones de Valparaíso, 19 de junio de 2013, rol № 1251-2013 (acción de protección). Disponible en: http://corte.poderjudicial.cl/SITCORTEPORWEB/.

Cereceda Bravo con Senado: Corte de Apelaciones de Valparaíso, 25 de marzo de 1993, roles $\mathrm{N}^{\circ}$ s. 45-93 y 48-93 (acción de protección), en: Revista de Derecho y Humanidades (año II, Nºs. 3 y 4), pp. 239-266.

Caso del Tribunal Constitucional vs. Perú: Corte Interamericana de Derechos Humanos, 31 de enero de 2001, serie C No 71. Disponible en: http://www. corteidh.or.cr/docs/casos/articulos/Seriec_71_esp.pdf.

Marbury v. Madison, 5 U.S. 137 (1803).

Cooper v. Aaron, 358 U.S. 1 (1958).

\section{OTRAS FUENTES CITADAS}

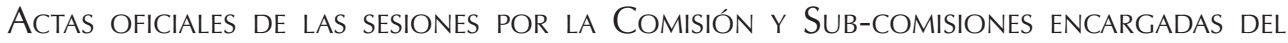
estudio del proyecto de la nueva Constitución Política de la República (1925), Imprenta Universitaria, Santiago.

Actas Oficiales de la Comisión Constituyente (1975-1981), Talleres Gráficos Gendarmería de Chile, Santiago.

Boletín de las Sesiones de la Cámara de Diputados, legislatura 361ª, sesión 6a , 20 de marzo de 2013 (acusación constitucional contra Harald Beyer).

Boletín de las Sesiones de la Cámara de Diputados, legislatura $337^{a}$, sesión $1^{\text {a }}$, 17 de marzo de 1998 (acusación constitucional contra Augusto Pinochet).

Boletín de las Sesiones de la Cámara de Diputados, legislatura 350a, sesión $34^{\mathrm{a}}, 16$ de diciembre de 2003 (acusación constitucional contra Iván de la Maza).

Boletín de las Sesiones de la Cámara de Diputados, legislatura 353a, sesión 9a, 22 de junio de 2005 (acusación constitucional contra Domingo Kokisch, Eleodoro Ortiz y Jorge Rodríguez).

Boletín de las Sesiones de la Cámara de Diputados, legislatura 352a , sesión 13a ${ }^{a} 3$ de noviembre de 2004 (acusación constitucional contra Luis Bates).

Boletín de las Sesiones de la Cámara de Diputados, legislatura 339a, sesión 4a, 13 de octubre de 1998 (acusación constitucional contra Ricardo Lagos).

Boletín de las Sesiones de la Cámara de Diputados, legislatura 335a, sesión 19a, 15 de julio de 1997 (acusación constitucional contra Servando Jordán, Marcos Aburto, Enrique Zurita y Osvaldo Faúndez). 
Boletín de las Sesiones de la Cámara de Diputados, legislatura $342^{a}$, sesión $30^{a}$, 29 de agosto de 2000 (acusación constitucional contra Luis Correa).

Boletín de las Sesiones de la Cámara de Diputados, legislatura 333a , sesión 33a, 4 de septiembre de 1996 (acusación contra Eleodoro Ortiz, Enrique Zurita, Guillermo Navas y Hernán Álvarez).

Boletín de las Sesiones de la Cámara de Diputados, legislatura 329a, sesión 3a, 31 de mayo de 1994 (acusación constitucional contra Alejandro Hales y Alejandro Foxley). 